\title{
Opportunistic Political Cycles: Test in a Young Democracy Setting ${ }^{\nabla}$
}

\author{
Akhmed Akhmedov ${ }^{\sharp}$ \\ and \\ Ekaterina Zhuravskaya ${ }^{\otimes}$
}

This draft: November $2003^{\oplus}$

\begin{abstract}
This paper tests the theory of opportunistic cycles in a decade-old democracy, Russia, finds strong evidence of cycles, and provides explanation for why previous literature often found weaker evidence. Using the comprehensive list of Russia's regional elections and regional monthly panel data between 1996 and 2003, we find that: (1) budget cycle is very sizable and short-lived: large expansion and contraction in fiscal spending occur within two months of elections on both sides; (2) the magnitude of the cycle decreases with government transparency, level of regional democracy, and voter awareness; (3) cycle becomes smaller over time; (4) pre-electoral manipulation increases incumbents' chances for re-election. The results confirm theoretical findings that maturity of democracy, transparency, and voter awareness are important in determining the scope for opportunistic cycles. The short length of the cycle explains underestimation of its size by previous literature because of low frequency data used.
\end{abstract}

JEL codes: H72, P35, P16, E32

Keywords: Opportunistic political cycles, Maturity of democracy, Russia, Fiscal policy, Government transparency

Email of corresponding author: zhuravsk@ias.edu

\footnotetext{
${ }^{\nabla}$ We thank Alessandra Casella, Sergei Guriev, Eric Maskin, Viktor Polterovich, Gèrard Roland, Thomas Romer, Paul Seabright, Claudia Senik, Andrei Shleifer, two anonymous referees, seminar participants at the New Economic School, CEFIR, Ohio State University, and the participants of the CEPR-WDI 2002 Transition Conference and the EEA 2002 Meetings for useful comments. We thank Alexander Andriakov, Yury Andrienko, and Konstantin Kozlov for help with data collection. We are grateful to the New Economic School for financial support and Alexei Ravitchev for excellent research assistance in the early stages of this project.

${ }^{*}$ Center for Economic and Financial Research (CEFIR)

${ }^{\otimes}$ Institute for Advanced Study, Princeton; CEFIR; and CEPR

${ }^{\oplus}$ The first draft was entitled "Regional Political Cycles in Russia” and dated June 15, 2002.
} 
"You can fool some of the people all of the time, and all of the people some of the time, but you cannot fool all of the people all of the time."

(Attributed to Abraham Lincoln, 1809-1865)

\section{Introduction}

Despite the fact that theoretical research on opportunistic political cycles is very intuitive and well developed, empirical literature produced mixed results in attempts to find convincing evidence of opportunistic cycles for almost a quarter of a century after pioneering work of Nordhaus (1975). The evidence from developed countries is particularly weak. ${ }^{1}$ This apparent contradiction between the theory and evidence created an intellectual puzzle. Why did many tests fail? Should the theory or the empirics be held responsible? Motivated by this gap, several recent theoretical works argued that opportunistic cycles should be most sizable in countries with immature democratic regimes. ${ }^{2}$ The evidence has been strongly supportive of this view: the cross-country comparisons with large presence of young democratic regimes and within-country studies of immature democracies have shown significant and robust fiscal cycles almost exclusively. ${ }^{3}$ Many of the tests, however, suffer from data limitations, in particular, insufficient frequency and, often, too high level of aggregation. ${ }^{4}$ This paper sheds further light on the puzzle by documenting very strong evidence of opportunistic cycles using detailed regional monthly panel data from a decade-old democracy.

\footnotetext{
${ }^{1}$ See Alesina, Roubini, and Cohen (1997), Drazen (2000), Franzese (2002), and Brender and Drazen (2003) for detailed surveys of theoretical and empirical literatures.

${ }^{2}$ See, for instance, Gonzalez (2000) and Shi and Svensson (2002a).

${ }^{3}$ See evidence and discussion in Brender and Drazen (2003) as well as evidence produced by Gonzalez (2002), Krueger and Turan (1993), Drazen and Eslava (2003), Block (2001), Block, et al. (2001), Shi and Svensson (2002a), and Shi and Svensson (2002b).

${ }^{4}$ Drazen and Eslava (2003) show that, to identify the cycle, it may be important to look at the composition of the budget rather than the aggregate fiscal spending.
} 
According to the theory, asymmetric information, awareness, and immaturity of democracy magnify the size of opportunistic cycles. ${ }^{5}$ Thus, the maximum possible size of the cycles should be observed in environments with these properties. Thus, Russia's regional elections of executives provide an ideal case for an empirical test of opportunistic political cycle theory. First, Russian democracy is very young and many regions are notorious for governor's control over mass media and large fraction of uninformed, naïve and myopic electorate. Second, detailed monthly regional-level data allow more powerful tests of the theory than the ones done so far. And third, high regional variation in possible determinants of cycles, on the one hand, and high uniformity in variables that are important to control for, i.e., electoral institutions, scope for policymaking, culture, trust, etc., on the other, help to analyze what drives variation in the magnitude of cycles. ${ }^{6}$

We test for presence of political cycles in Russian regional elections in a wide range of fiscal policy instruments as well as economic outcomes. Then, we address the question of how awareness of voters, their access to unbiased information, maturity of democracy, and voter experience affect cycle magnitude. Finally, we study whether opportunistic cycles help governors to get reelected.

We find cycles in regional fiscal policies controlling for region-specific characteristics, federal trend, seasonality, and fluctuations driven by differences in ideology (partisan cycles). ${ }^{7}$ Total budgetary expenditures, spending on education, healthcare, social disbursements, industrial subsidies, and mass media as well as repayments of wage arrears to public workers exhibit sizable and very short cyclical

\footnotetext{
${ }^{5}$ Rogoff and Sibert (1988), Rogoff (1990), Gonzalez (2000), and Shi and Svensson (2002a).

${ }^{6}$ Persson and Tabellini (2003) show that electoral institutions are important determinants of cycles.

${ }^{7}$ See Alesina, Roubini, and Cohen (1997) for a review of partisan cycles.
} 
pattern. The biggest in magnitude cycles are observed in repayment of wage arrears and social expenditures. Even though spending starts to grow gradually approximately nine to six months before elections, the largest (significant) jump takes place one or two months before elections. Right after elections spending drops and wage arrears start to accumulate. Industrial growth is not significantly affected by elections in line with the empirical literature and in contrast to predictions of the first wave of non-rational Keynesian-style opportunistic models (Nordhaus, 1975).

Use of monthly panel data allowed us careful measurement of even very short cycles. This turned out to be important because most sizable increases in spending happen a month before and decreases a month after elections, thus, use of lower frequency data would have lead to substantial underestimation of cycles. To the best of our knowledge all empirical studies on developing countries so far used quarterly or lower frequency data. Very short cycles, however, cannot be clearly seen in quarterly data because elections often take place in the middle of the quarter and the opposite-sign deviations from the trend around elections cancel out in data with low frequency. ${ }^{8}$ It is important to note that the short length of the cycle does not mean that the cycles are not of any quantitative importance. First, poor voters who are the primary target of the cycle (public workers on budget payroll and recipients social disbursements) have the worst possibilities for consumption smoothing. Second, irrespective of the driving force of the cycle - asymmetric information or voter inexperience (myopia) - it indicates the absence of checks and balances on politicians common in mature democracies (i.e., separation of powers, free media, active NGOs, etc.) that give voters fuller information and longer-

\footnotetext{
${ }^{8}$ The only paper that uses monthly data is Berger and Voitek (1997). They reject hypothesis of opportunistic cycles for the German developed democracy.
} 
term control over politicians and, therefore, limit possibilities for misuse of public office for private gain. Thus, large and short-lived cycles provide evidence of poor long-term accountability of politicians.

What determines the magnitude of cycles? In line with the latest theoretical findings of the literature, we find that proxies for informational symmetry (freedom of media and transparency of regional governments), voter awareness (education level and urbanization) as well as the level of regional democracy significantly reduce cycles. In addition, cycles get smaller over time, which could be an indication of voter learning as Russia's democracy matures or an effect of the change of president (data are insufficient to distinguish between these two hypotheses). We also find that cycles in fiscal policy instruments significantly increase popularity of incumbents and help them win. Our results suggest that maturity of democracy is a very important factor determining the scope for effective use of political cycles: it pays in young democracies and it does not in the environments with high voter awareness and developed democratic institutions.

The remainder of the paper is organized as follows. The next section briefly overviews the findings of previous literature. Section 3 describes the data. Section 4 formulates hypotheses and empirical methodology. Section 5 presents the results. Section 6 concludes.

\section{Previous literature}

Two strands of literature, opportunistic political business cycles and partisan theory, explain inefficient economic fluctuations around elections. The literature on opportunistic cycles argues that electoral pressure forces politicians to manipulate public policy in order to increase chances of reelection with the help of pre-electoral 
improvements. Low asymmetry of information between politicians and the public, awareness of voters, availability of institutional checks and balances, and maturity of democracy reduce opportunistic cycles. The alternative approach - partisan theory argues that policies are predetermined by ideology. Economic fluctuations arise as a result of policy changes when different parties alternate in office: each party in office focuses on the short run improvements for its own constituency. ${ }^{9}$

Kalecki (1943) was the first to develop the idea that politicians might alter policies in the face of elections. Subsequently, theory of opportunistic cycles and partisan theory developed in parallel. The theoretical literature came in two waves. The first "nonrational” wave came in 1970s. Nordhaus (1975) built the first opportunistic model based on adaptive expectations of voters. Hibbs (1977) developed the first partisan model. Frey (1978) and Frey and Schneider (1978) combined the features of opportunistic theory and partisan theory to develop weak partisan theory. The second wave reconciled rational expectations with political cycles. Alesina (1987) built the rational partisan theory that attributed cycles to wage rigidities and uncertainty of election's outcome. Rogoff and Sibert (1988), Rogoff (1990), and Persson and Tabellini (1990) modeled rational opportunistic cycles that are based on asymmetry of information between the incumbent politician and the voters. Adaptive expectations models exploited the Phillips curve framework and, thus, predicted cycles in growth, unemployment, and inflation. Opportunistic models based on rational expectations predicted cyclical pattern in fiscal policies rather than real outcomes. ${ }^{10}$ Recently, Gonzalez (2000) extended the rational

\footnotetext{
${ }^{9}$ Binding commitments to co-operative common policy rule and reputation reduce partisan cycles.

${ }^{10}$ Keller and May (1984) were the first to argue that one needs to look at the political actions rather than the real economic outcomes to find evidence of opportunistic cycles based on analysis of President Nixon's election campaign. Overall, pure (non-rational) theories à la Nordhaus (1975) and Hibbs (1977) are proven
} 
signaling models to accommodate importance of the institutional context of policymaking: transparency and maturity of democratic traditions. Shi and Svensson (2002a) modeled the effect of a change in a fraction of uniformed voters on the magnitude of rational cycles in a moral hazard framework.

Empirical research in developed countries so far revealed much stronger evidence of partisan compared to opportunistic cycles. Using quarterly post-war US data, Alesina and Sachs (1988) found strong support for rational partisan theory and Klein (1996) little support for opportunistic cycles. Berger and Woitek (1997) rejected both partisan and opportunistic cycles in Germany on monthly data. Reid (1997) relaxed the assumption of exogeneity of election time and found weak evidence of opportunistic cycles in Canadian provinces. Alesina and Roubini (1992) tested the competing theories in a unified framework, using panel of 18 OECD countries with quarterly data, and found strong robust support of rational partisan cycles and, in selected countries, some evidence of rational opportunistic cycles.

Non-convincing evidence of opportunistic cycles in developed countries motivated the new wave of empirical research that uses data from developing countries with an emphasis on the determinants of cycles. Schuknecht $(1998,2000)$ found evidence of cycles in budget expenditures and investment based on quarterly panel data for 25 developing countries and showed that cycles are much larger in countries with low inflation costs. Block (2001) used annual data for 69 developing countries to show that budget cycles took place only in countries with sufficient electoral competition. Block, et al. (2001) confirmed this result on data for 44 African countries. In addition, they found

to be inconsistent with results of virtually all empirical tests: Drazen (2000) surveys empirical literature to show that, when found, cycles affect fiscal and monetary policies rather than growth or unemployment. 
that cycles got weaker as voters learned. Gonzalez (2002) found evidence of budget cycles in Mexico and showed that they are related to the levels of democracy and transparency. Shi and Svensson (2002b) analyzed data from 123 countries and found some evidence of cycles both in developed and developing countries with significantly stronger evidence in developing countries. Persson and Tabellini (2003) also provided evidence of budget cycles both in developed and developing countries. Subsequent work of Brender and Drazen (2003) showed that the evidence of cycles in developed countries is unrobust and depends on few influential observations, whereas evidence from developing countries is driven by immature democracies.

Overall, recent research with the focus on fiscal instruments in young democracies produced more convincing evidence of opportunistic cycles. This evidence, however, is not always as strong as one could expect. Important reason for this is underestimation of the cycle due to insufficient frequency of data; we address this problem in this paper.

\section{The data}

The comprehensive list of regional governor elections that took place and will take place in Russia between August 1995 and December 2003 consists of 194 electoral events. ${ }^{11}$ Data on most policy instruments and outcomes are available for 159 elections that took place in the period between September 1996 and July 2003. Four regions had three rounds of elections, sixty-five regions had two rounds of elections, and seventeen regions had just one round of elections during this period. The source of data on elections is Tsentrizbirkom, the Central Elections Committee of the Russian Federation.

\footnotetext{
${ }^{11}$ This list covers all the regions but Dagestan, the only region where the governor is appointed. We also excluded data for Chechnya and Ingushetia from our sample because the fluctuations in fiscal policies of these regions have been driven by war rather than elections.
} 
Regional monthly series of fiscal instruments and outcomes come from two sources: Goskomstat, the State Committee of Statistics, provided data on wages and income, wage arrears from the regional budgets, price level, and industrial output between 1995 and 2003; the Ministry of Finance of the Russian Federation provided detailed data on execution of regional budgets for the period between 1996 and 2003.

To test for the determinants of cycle magnitude, we use cross-section data. Data on urbanization and education come from Goskomstat. The data on freedom of media in the regions were provided by the Institute of Free Media (www.freepress.ru). Data on transparency of the regional government come from "Media-Soyuz," an independent professional association of Russian journalists. Data on the scope of regional democracy are from Nikolay Petrov of the Carnegie Moscow Center, Carnegie Endowment for International Peace (Petrov, 2001). Appendix presents descriptive statistics of the data. In many cases, simple plots of actual series of regional spending suggest vivid increases in spending prior to elections (some examples are given in figure 1). One of the tasks of this paper is to find out if the results of a "visual test" survive rigorous econometric analysis.

\section{Hypotheses and empirical methodology}

\subsection{Test of opportunistic cycles}

Theory of opportunistic cycles predicts that governors pursue expansionary fiscal and/or monetary policies before elections irrespective of their ideological platform. We test whether these predictions are consistent with the data treating election time as exogenous. $^{12}$

\footnotetext{
${ }^{12}$ Reid (1997) and Heckelman and Berument (1998) pointed out that opportunistic cycles can also occur as a result of setting election date at a time of a boom. Although almost $19 \%$ of Russia's regional elections happened a month or more of their expected date; in vast majority of these cases, however, the time was
} 
To test the existence of cycles and analyze their duration, we utilize the event study methodology. The following specification of panel regressions with regional fixedeffects was used:

$\ln \left(y_{i t}\right)=\alpha+\sum_{j \in\{-12 ; 12\}} \alpha_{j} m_{j i t}+\sum_{j \in\{i ; 4\}} \beta_{j} \ln \left(y_{i t-j}\right)+\gamma_{1} \operatorname{Term}_{i t}+\gamma_{2}$ Left $_{i t}+f_{i}+\varepsilon_{i t}$

where $i$ - region; $t$ - ordinal number of a particular month. $y$ stands for a de-trended monthly instrument or outcome of regional policy. ${ }^{13}$ We consider three groups of policy instruments and outcomes: budgetary expenditures (total budgetary expenditures as well as levels and shares of expenditures on social programs, education, culture, healthcare, mass media, and subsidies to industry and agriculture), budgetary revenues and deficit (total budgetary revenues, tax revenues, federal transfers, and deficit) ${ }^{14}$ and such outcomes as growth, inflation, regional wage arrears, wage level, and money income.

$m_{j i t}$ is a dummy that equals 1 , if $t$ is $j$ months away from elections in region $i$ (negative $j$ means that $t$ is prior to elections, positive - that $t$ is after elections, $j=0$ in the month of elections). Significant coefficients at dummies indicating the time distance from elections $\left(\alpha_{j}\right)$ point toward the shifts in the autocorrelation process of the policy instrument. Thus, positive significant values of the estimates of $\alpha_{j}$ before elections and negative significant values of the estimates of $\alpha_{j}$ after elections would serve as evidence of the opportunistic political cycle.

shifted exogenously, because governors were promoted to the federal government before their terms ended. It is illegal to shift the date of regional elections in Russia. There were few cases, however, when there was no exogenous reason for the shift of election time. To make sure that our results are not driven by presence of endogenous elections, we repeated all tests on the subsample of elections that had exogenously predetermined timing and got virtually identical results.

13 The detailed description of how the policy instruments were de-trended is presented below in this section.

${ }^{14}$ We look at the federal transfers conditional on them being positive. 
Term controls for incumbent's political horizon. ${ }^{15}$ It equals 0,1 , 2, or 3 depending on which term the governor serves in office; 0 indicates that the governor is appointed and has not been elected before; 1 indicates that the governor was elected for the first time, etc. $f_{i}$ are regional fixed effects. ${ }^{16}$

$\ln \left(y_{i t-j}\right), j \in\{; ;\}$ account for autocorrelation in the series of policy instruments. We tested the optimal lag structure of the model using Akaike criterion. Inclusion of four lags turned out to be optimal in terms of fit for the vast majority of the series. ${ }^{17}$ Lags in panel regressions may bias the estimators (Hansen, 1982 and White, 1982). The bias converges to zero when time dimension of a panel goes to infinity. Our monthly panel covers above eighty months (seven years). Therefore, the asymptotic properties can be applied. Nonetheless, we re-estimated equation (1) using the Arellano-Bond procedure (Arellano and Bond, 1991). The results were not changed by this technique.

Electoral campaign platforms of Russia's governors are polarized into the "communist left" and the "liberal-democratic ideology." Left is a dummy that equals 1 if the incumbent governor is supported by the Communist Left wing coalition. This dummy controls for partisan cycles. ${ }^{18}$

An important methodological question is how to control for the macroeconomic shocks and the federal policy that affect regions. In particular, this is essential, because in

\footnotetext{
${ }^{15}$ Besley and Case (1995) built a theoretical model and provided empirical evidence that gubernatorial term limits are an important determinant of fiscal policies.

${ }^{16}$ The regression has a constant term because $f_{i}$ 's joint mean is normalized to zero.

${ }^{17}$ The results are robust to using higher order lag polynomials and to the use of other criteria of autoregressive-model selection. For the sake of uniformity, we report results with four lags for all the series, but results do not change if we include optimal number of lags determined separately for each of the series.

${ }^{18}$ Partisan theory implicates a priori differences in ideology: "communist left" ideology opts for a larger size of government and larger redistribution. This implies that, ceteris paribus, social expenditures, government deficit, and inflation should be greater if communist governors are in power. In practice, the variation in the data is insufficient to have a proper test of partisan theory because there are only few cases when new governor of the opposite ideological platform replaced an incumbent governor after elections; and, therefore, ideology of governors is almost perfectly collinear with regional fixed effects. Thus, we do not put emphasis on interpretation of coefficient of the "left-wing" dummy.
} 
1996 at one instance several regional elections and the federal elections took place in Russia. In order to eliminate the effects of the federal policy (which can also be cyclical in the face of federal elections) we tried each of the three following options (used by Alesina and Roubini, 1992). First, we divided each policy instrument by its federal level (calculated as population-weighted average of the regional values). Second, we added federal trend as regressor. Third, we added month dummies as regressors. The results of these three approaches are very similar, thus, throughout the paper we use specification of the first approach: all considered policy instruments and outcomes are de-trended.

Another methodological question is how to control for seasonal fluctuations. It is important because a large portion of regional elections had taken place in the same months (elections frequently took place at the end of the year, particularly, in December). We tried the following alternative strategies. First, to control for the common to all regions seasonal fluctuations, it is sufficient to include dummies for calendar month in the regression or de-trend as described in the previous paragraph. Second, to control for region-specific seasonality, we included fixed effects for each of the region-month combinations (86 regions times 12 calendar months) in equation (1). Each strategy produced very similar results in magnitude with a slight loss of significance in the latter case due to a considerable fall in the number of degrees of freedom. As a baseline, we report regression results that control for common to all regions seasonality.

\subsection{Determinants of opportunistic cycles}

The second step of our analysis is the study of the determinants of cycle magnitude. We test the predictions of the theory that the size of opportunistic cycles is negatively related to awareness of voters, access to unbiased sources of information, and 
the maturity of democracy (Rogoff and Sibert, 1988, Gonzalez, 2000, and Shi and Svensson, 2002a).

The best way to test for the determinants of the magnitude of the cycle is to run specification (1) with additional regressors that proxy for possible determinants of the cycle - awareness, democracy, and government transparency $\left(R_{i}\right)$ and voter learning $\left(\right.$ Time $\left._{t}\right)$ - and their interaction with the pre-election month dummies $\left(m_{j i t} R_{i}\right)$ and $\left(m_{\text {jit }}\right.$ Time $\left._{t}\right) .{ }^{19}$ We use the following measures of awareness: the log share of population with higher education and the log share of urban population. As proxies for government transparency (informational asymmetry) we use indices of freedom of media production in the region and transparency of regional government. We also look at the effect of the level of regional democracy. All these measures are available only as cross-section. ${ }^{20} \mathrm{We}$ run the full panel with 12 month dummies before and after elections (analogous to (1)), but for the presentation purposes we report a shorter version that preserves the main results from the longer specification:

$\ln \left(y_{i t}\right)=\alpha+\sum_{j \in\{-3 ; 3\}} \alpha_{j} m_{j i t}+\sum_{j \in\{-3 ; 0\}} \eta_{j} m_{j i t} R_{i}+\sum_{j \in\{-3 ; 0\}} \xi_{j} m_{j i t} T_{i m e_{t}}+\xi \operatorname{Time} e_{t}+\sum_{j \in\{i ; 4\}} \beta_{j} \ln \left(y_{i t-j}\right)+\gamma_{1} \operatorname{Term}_{i t}+\gamma_{2}$ Left $_{i t}+f_{i}+\varepsilon_{i t}$

As $y_{i t}$, we used only fiscal policy instruments, since they turned out to exhibit significant cycles after estimation of equation (1). Negative significant coefficients at $m_{j i t} R_{i}$ and $m_{j i t}$ Time $_{t}$ are interpreted as evidence that awareness, democracy, government

\footnotetext{
${ }^{19}$ Henceforth, in addition to using Time as a proxy for learning, we consider the number of previous elections in a particular region (we call this variable Round). These two proxies are correlated.

${ }^{20}$ All of these measures (education, urbanization, freedom of media, government transparency, and democracy) are positively correlated with each other. All correlations are highly significant except for the correlation between education level, on the one hand, and democracy and government transparency, on the other. Proxies for voter awareness reflect both the possibilities of electorate to get access to necessary information (i.e., internet and TV) which is easier in urban areas as well as the ability (experience) of electorate to process this information that comes with education level.
} 
transparency, and voter experience are associated with lower amplitude of the cycle (given that coefficients at respective $m_{j i t}$ are positive).

The fact that $R_{i}$ does not vary across time and for four of the five measures varies only a little across regions (summary statistics are provided in appendix) creates a problem in estimation of this panel because regressors $m_{j i t} R_{i}$ and $m_{j i t}$ are correlated. Thus, to make sure that our results are not driven by this correlation we also report the results of the following cross-section test.

As a cross-section measure of the magnitude of the cycle in a particular fiscal policy instrument for a particular election, we take the pre-electoral month deviation of the value of that policy instrument from the regional trend net of seasonal fluctuations. Thus, we define cycle amplitudes as pre-electoral month residuals from estimation of the following equation run separately for each region in the sample:

$\ln \left(y_{i t}\right)=\sum_{j \in\{1 ; 12\}} \alpha_{j} d m_{j t}+\beta$ Time $_{t}+\varepsilon_{i t}$

$d m_{j t}$ in equation (2) stands for month dummies corresponding to 12 calendar months. Time $_{t}$ is the real time in months. Summary statistics for each individual proxy of the amplitude are presented in table 1. For all fiscal policy instruments, the mean amplitudes are positive and, for nine out of twelve, they are significantly different from zero. In addition to considering the amplitudes in each budgetary item separately, we constructed an aggregate measure of magnitude as the first principal component of the amplitudes in individual fiscal policies with the most profound electoral cycle, viz., total budgetary 
expenditures, social expenditures, expenditures on culture, education, mass media, and regional industrial subsidies. $^{21}$

To examine which factors influence the magnitude of the cycles, we run the following equation on the pooled cross section of elections:

$$
A_{i}=\beta_{0}+\beta_{1} R_{i}+\beta_{2} \text { Time }_{i}+\varepsilon_{i}
$$

where $i$ is the ordinal number of elections. $A_{i}$ is the amplitude of the cycle (as described above). $R_{i}$ is a proxy for awareness, democracy, and government transparency (as above). ${ }^{22}$ Time $_{i}$ is a proxy for voter experience measured in years. In estimation of equation (3), we excluded elections that took place in 9 Autonomous Okrugs that are subdivisions of other larger regions because for the most part $R_{i}$ data are unavailable for them. Equation (3) has regional-level regressors; thus, we allow error terms to be clustered (correlated) among observations within the same regions.

Learning by voters is not the only possible interpretation of the negative influence of Time on the magnitude of the cycle, however. An alternative story is the disciplining role of increased central control over regions during Putin's compared to Yeltsin's administration. Although, there has not been any formal institutional change in the regional electoral mechanism or authority of regional governments over spending from Yeltsin's to Putin's time, one could argue that Putin has monitored regional governments

\footnotetext{
${ }^{21}$ The first principal component explains $47 \%$ of the total variation in these measures. The factor loadings are as follows: 0.73 (Total Budget Expenditures) + 0.59 (Social Expenditures) + 0.74 (Expenditures on Culture) +0.80 (Education Expenditures) +0.42 (Media Expenditures) +0.21 (Expenditures on Industry). ${ }^{22}$ In cross-section regressions, instead of the entire index of democracy, we use dummy that indicates if a region has a value of democracy that is above the median (this proxy gives us better fit, possibly because of poor cardinal properties of the index).
} 
more closely. In attempt to separate these hypotheses we run regressions (1`) and (3) separately for periods when each of the presidents was in power. ${ }^{23}$

\subsection{Do cycles help wining?}

Finally, we investigate whether it pays to pursue cyclical policies. ${ }^{24}$ To test whether cycles helped incumbent governors to get re-elected, we estimate how the probability to win and the share of incumbents' votes depend on the amplitude of the cycles, controlling for the ideology of incumbent governor and governor's performance in the last term. We also test if the effect of cycles on the probability to win depends on awareness, democracy, and learning. We estimate the following equations on the pooled cross section of elections:

$\ln \left(P_{i}\right)=\gamma_{0}+\gamma_{1} A_{i}+\gamma_{2}\left(R_{i}-\bar{R}\right)\left(A_{i}-\bar{A}\right)+\gamma_{3}\left(A_{i}-\bar{A}\right)\left(\right.$ Time $\left._{i}-\overline{\text { Time }}\right)+\gamma_{4}$ Left $_{i}+\gamma_{5}$ Time $_{i}+\gamma_{6}$ Perform $+\gamma_{7} R_{i}+\varepsilon_{i}$

and

$\operatorname{Prob}\left\{\text { incumbent - below the } 2^{\text {nd }} \text { place; incumbent - the } 1^{\text {st }} \text { runner up; incumbent wins }\right\}_{i}=$

$=\phi \gamma_{0}+\phi_{1} A_{i}+\phi_{2}\left(R_{i}-\bar{R}\right)\left(A_{i}-\bar{A}\right)+\phi_{3}\left(A_{i}-\bar{A}\right)\left(\right.$ Time $\left._{i}-\overline{\text { Time }}\right)+\phi_{4}$ Left $_{i}+\phi_{5}$ Time $_{i}+\phi_{6}$ Perform $_{+}+\phi_{7} R_{i}+\varepsilon_{i}$

where $P_{i}$ is the popularity of incumbent measured by the ratio of votes for incumbent to votes for the most popular challenger on elections $i . A_{i}$ is the proxy for the aggregate amplitude of the cycles prior to elections $i$, equal to the first principal component of the amplitudes of fiscal policies as in equation (3). The cross-terms $\left(R_{i}-\bar{R}\right)\left(A_{i}-\bar{A}\right)$ and $\left(A_{i}-\bar{A}\right)\left(\right.$ Time $\left._{i}-\overline{\text { Time }}\right)$ are included to test whether awareness, democracy, transparency,

\footnotetext{
${ }^{23}$ If Time does have an effect within subsamples, one could argue that learning takes place. If, however, Time comes out insignificant, we cannot differentiate between the two hypotheses because insignificance of time within subsamples could be attributed to clustering of election dates or reduction in the number of observations.

${ }^{24}$ Russia's incumbent governors have been active in trying to retain power (90\% of them ran for reelection) and they have been more successful than the opposition in attaining votes (65\% of those who ran for another term won). This proportion is significantly larger than a half at $1 \%$ significance level. This incumbency bias is quite high considering deep recession that Russia experienced for a large part of transition.
} 
and learning reduce effectiveness of cycles. ${ }^{25}$ Positive significant coefficient at $A_{i}$ is an indication that cycles help incumbents to get reelected (in line with opportunistic political cycle theories); negative significant coefficients at cross-terms indicate that $R_{i}$ and Time $_{i}$ reduce the influence of cycles on chances of reelection. Control variables are as follows: Left $_{i}$ is as described above. Perform ${ }_{i}$ is a vector of proxies for governor's performance in the last term comprised of the differences between the overall regional means and the regional means over the last term for the following variables: log share of social expenditures, log of per capita regional product and log of price level. ${ }^{26}$

Equation (5) is the multivariate ordered probit model with the same set of regressors as in (4) and with three outcomes for the incumbent: wins, is the first runner up, is below the second place. ${ }^{27}$ In estimation of equations (4) and (5), from the sample we exclude elections with the single candidate, elections, in which incumbent did not run for reelection and did not name his successor, and (as above) elections in Autonomous Okrugs. In addition, we used Cook’s distance approach (Cook, 1977) to exclude four outliers that had excessively strong effect on our estimates. Just as in equation (3), in equations (4) and (5) we allow error terms to be clustered within regions.

There is an endogeneity problem in estimation of equations (4) and (5), however. If governors are sure of wining because their rating is too high, they have weak incentives to use cyclical policy because of the costs of pre-electoral distortions. In this case, the

\footnotetext{
${ }^{25}$ Upper bars denote the mean values. Subtraction of means before taking the cross-term does not change the interpretation of the coefficient at the cross-term, but makes the interpretation of the coefficients of $A_{i}$ easier: it becomes equal to the full effect of the amplitude, evaluated at $\bar{R}$ and $\overline{\text { Time }}$.

${ }^{26}$ There are a number of additional proxies that we used to control for governor's performance (as a robustness check), i.e. relative income, relative taxation level, and relative growth rate in all of the performance indicators considered. The main results do not depend on the choice of controls for past governor's performance.

${ }^{27}$ We also estimate simple probit model with two outcomes: wins/loses. Both approaches produce almost identical results.
} 
tighter the electoral competition, the higher the incentives for pre-electoral manipulations. This link from popularity to incentives for cyclical behavior implies negative correlation between popularity and cycles. Thus, if there are governors that are sure of re-election, we are likely to underestimate a positive causal relationship between the magnitude of the cycles and the probability to win with regressions (4) and (5). ${ }^{28}$ One could argue that too low probability to win may also reduce incentives for cyclical policy because expected gains from elections are lower than costs of distortions in this case. This would have implied that we overestimate the causal effect of cycles on popularity. There have not, however, been regional elections so far in Russia where incumbent governors did not have a good chance of wining. ${ }^{29}$ Therefore, overall we are likely to underestimate the effect.

\section{Results}

\subsection{Evidence of cycles}

The results of estimation of equation (1) are presented in tables 2 and 3. Table 2 presents regression results for fiscal policy instruments. Figure 2 presents predicted by these results political budget cycle for a number of budgetary items measured in percentage deviations from the trend around elections. Total budgetary expenditures experience the first significant jump up of $5 \%$ that takes place only three months before elections (prior to that coefficients are mostly positive, but insignificant); the next rise in expenditures of $9 \%$ happens one month before elections. The total increase in the budget

\footnotetext{
${ }^{28}$ Cook's distance approach (Cook, 1977) eliminated observations in which incumbents had the highest political rating. Therefore, it partly eliminated this problem.

${ }^{29}$ In order to make sure that we do not overestimate the effect of cycles on probability to get re-elected we re-estimated the equations (4) and (5) on the subsample of elections prior to which incumbent was at least twice as popular as the main opponent and got similar results. Instrumenting the amplitude is the way to solve this problem altogether, but we do not have a good instrument.
} 
spending during the year prior to elections amounts to $13 \%{ }^{30}$ The election month and the month right after the elections are characterized by significant decreases in total budget expenditures (the total decrease in these two months amounts to 17\%). We do not find significant changes in total expenditures after two month following elections. Budgetary expenditures on education, culture, and healthcare follow a similar pattern: All three expenditure items exhibit significant increases in the two months prior to elections: of 13, 11 , and $11 \%$, respectively. These expenditure items fall significantly by 13,19 , and $12 \%$, respectively, during the two months right after elections. ${ }^{31}$

Cycle in social spending item is more gradual: it rises significantly by $6.1 \%$ nine months before elections and, then, jumps up each month prior to elections starting five months before elections. During the month right before elections alone social expenditures rise by $18 \%$. Accumulated growth in social expenditure over a half a year before elections amounts to 34\%. Social expenditures do not drop below the overall trend as other expenditure items do after the elections: there is only one significant drop of $23 \%$ one month after elections.

Expenditures on industry (e.g., industrial subsidies) first rise significantly by $12 \%$ nine months before elections and, then, rise significantly for two months prior to elections. The total increase in industrial subsidies in the two months before elections amounts to $28 \%$. During two months following elections industrial subsidies fall by $32 \%$.

Cyclical dynamics in social expenditures and industrial subsidies is supported by the intensive use of mass media. Expenditures on media exhibit first jump of 17\% ten months before elections. Growth continues closer to elections: media spending increases

\footnotetext{
${ }^{30}$ Henceforth, cumulative changes are calculated by comparisons of fitted values (see figure 2 for the illustration).

${ }^{31} 11$ and 10 months prior to elections education expenditures exhibit fluctuations that cancel each other out.
} 
by $30 \%$ during half a year preceding elections. This spending item drops $35 \%$ in the two post-electoral months.

Investigation of pre-electoral dynamics in composition of budget spending shows that changes in social and media expenditures and industrial subsidies are disproportionately large compared to the other expenditure items. Share of social expenditures in total spending rises by $19 \%$ during the half a year prior to elections. Share of media expenditures jumps by $22 \%$ during the same period. In the pre-electoral month, shares of spending on social disbursements, media, and industrial subsidies reach the levels that are 18, 20, and $14 \%$ higher than their levels during times away from elections.

The rise in expenditures is financed in part by increases in non-tax and tax revenues, in part by an increase in deficit and (for regions-recipients of federal grants) in part by increased federal transfers. Total revenues exhibit an increase of about $5 \%$ in the pre-election month and a drop of $14 \%$ in the month of elections. Interestingly, federal transfers finance a significant chunk of pre-electoral manipulations: they rise by $16 \%$ one month before elections; then, fall approximately by about $28 \%$ right after the elections.

Table 3 presents the effect of elections on dynamics of economic outcomes and wage arrears. Regional growth does not exhibit a significant cyclical pattern. Inflation decreases throughout the half a year prior to elections (statistically significant drops in inflation take place in months $-6,-4,-1$, and 0 ). After the elections there is no statistically significant movement in inflation till month 11, when it increases. ${ }^{32}$ These two pieces of evidence indicate that politicians do not explore growth-inflation tradeoff to increase their chances of reelection, contrary to Nordhaus's prediction. Although these changes in

\footnotetext{
${ }^{32}$ Unemployment behaves similarly to growth.
} 
inflation are econometrically significant, they are much smaller in magnitude than fluctuations in fiscal policy instruments. Thus, our fiscal policy cycles results hold irrespective of whether we take real or nominal values of the policy instruments. ${ }^{33}$ Money income falls slightly in the middle of the year before elections, but grows in three preelectoral months, the total growth amounts to about 9\%. Wage level exhibits small significant jumps four months before elections and in the pre-electoral month (as a result, in the pre-electoral month it is $2 \%$ above the trend) and falls consistently for seven months after elections (only coefficient at dummy three months after elections is significant, however). The effect of elections on average wage and income seems to be driven by repayment of wage arrears to public workers from the regional budgets (and, thus, to the budget cycle): wage arrears from regional budgets significantly decline (almost) every month during the last ten months before elections. Wage arrears drop by $25 \%$ in the pre-election month alone. The total decline in the level of wage arrears amounts to 52\% during the year prior to elections: a year before elections wage arrears are at the level that is $39 \%$ above the trend and by the pre-election month they reach the level that is $13 \%$ below the trend.

Overall, we find very strong evidence of sizable opportunistic cycles in fiscal policies and no evidence of pre-electoral expansion in economic growth. Wage arrears repayments and social expenditures are the main instruments of fiscal pre-electoral manipulations. Cycles are very short: the largest shifts in policy instruments occur within a month or two from the election date.

\subsection{Evidence on determinants of cycle magnitude}

\footnotetext{
${ }^{33}$ As a baseline, we report dynamics of real values of policy instruments. We, however, also tested for presence of cycles in nominal expenditures directly (disregarding the price differences between regions). The results remained the same.
} 
Let us turn to the discussion of determinants of the size of cycles. Table 4 presents cross-section results (estimation of equation (3)). First, the data confirm the theoretical prediction that awareness of voters (measured by education and urbanization) reduces magnitude of the budget cycle. In all regressions, coefficients of proxies for awareness have the right sign. In eight out of twelve cases results are significant. Education and urbanization negatively significantly affect the aggregate measure of cycle magnitude. In addition, share of educated population significantly reduces cycles in education, cultural, and healthcare expenditures: A 10\% increase in the share of population with higher education decreases cycle magnitude by almost $2 \%$. Urbanization significantly affects cycles in total, social, and cultural expenditures: A $10 \%$ increase in the share of urban population leads to a decrease in the amplitude of cycle in total spending and spending on culture of about $2 \%$ and in social spending of $5 \%$.

Second, in line with prediction of Gonzalez (2000) that in the intermediate range of democracy levels, lack of democracy is what gives rise to election cycle (whenever democracy and transparency are related), we find that the magnitudes of the aggregate cycle as well as cycles in social and cultural expenditures are significantly smaller in more democratic regions. (Again, the effect of democracy has the right sign in all regressions.) The difference in magnitudes of cycles in social and cultural expenditures between regions with the levels of democracy above and below median is about one percent. Transparency of the government also significantly reduces cycles. A one standard deviation increase in the index of government transparency decreases cycles in social expenditures by 7 percent. A one standard deviation increase in the index of freedom of media leads to an $8 \%$ decrease in social expenditure cycle and a 5\% decrease in cycle in cultural expenditures. Again, in vast majority of cases (7 out of 12), 
coefficients of proxies for government transparency have the predicted sign; in the other three cases, the effect is essentially zero.

Overall, panel results (from estimation of equation (1`)) confirm the cross-section findings and, actually, in many cases, they are stronger. Table 5 presents panel results for healthcare expenditures, social expenditures, and the share of social expenditures (results for other fiscal policy instruments are very similar). The interaction terms of awareness, democracy, and transparency with pre-electoral month dummies usually have negative (often, significant) coefficients for the two months before elections indicating that these variables reduce the magnitude of the cycle. ${ }^{34}$

Time, our proxy for learning, also negatively significantly affects the size of the cycle both in cross-section (table 4) and panel (table 5) specifications. As shown in table 4, cycles fade away relatively fast: Each additional year on average decreases cycle magnitude by about 3\%. We also estimated the effect of an additional round of regional elections as was done by Block, et al. (2001): An additional election in a region reduces the magnitude of the cycles by over $30 \% .^{35}$ Thus, each new wave of regional elections had substantially smaller cycles. ${ }^{36}$ When we split the sample into two subsamples according to the change of presidents (from Yeltsin to Putin), both the cross-section and panel results that the time (and the round of elections) reduces the magnitude of cycle

\footnotetext{
${ }^{34}$ These results are robust to the number of pre-electoral dummies considered. They are also robust to accounting for $R_{i}$ and time influence in one specification or in the separate specifications.

${ }^{35}$ The estimated cross-section equation of the influence of the round of elections in a region on the amplitude of the cycle is as follows: $A_{i}=\underset{[3.19]}{0.838-0.401 \text { Round }_{i}}-{ }_{[1.04]}^{0.159}$ Left $_{i}+\varepsilon_{i}$. (Number of observations is $133 ; \mathrm{R}^{2}=0.085$.) Time in our opinion, however, is a more appropriate measure of voter learning because voters can learn from other electoral events like elections to the regional legislature and federal elections.

${ }^{36}$ One could suppose that the magnitude of the cycle would be affected by the level of the world price of oil because in times of high oil prices, governors may be less constrained in their pre-electoral fiscal manipulations. (A large chunk of budgetary revenues at all levels of government directly and indirectly depends on taxation of oil rents.) As a robustness check, we have controlled for the level of oil price in all regressions and for its interaction with the pre-electoral month dummies in panel regressions and found that none of our baseline results are driven by the dynamics of oil prices.
} 
become much weaker and, in most cases, disappear (there are few fiscal instruments for which the results remain strong, however). Indeed, most of the variation in time component of the cycle magnitude comes from comparison of the two waves of elections: where the first wave came under Yeltsin's administration and the second wave - under Putin's. Thus, we cannot clearly separate the two hypotheses about whether time reflects learning or informal changes in Russia’s federal control over regions.

\subsection{Effect of cycles on re-election}

Table 6 presents the results of the test of whether cycles help to get reelected (estimation of equations (4) and (5)). We find strong evidence of political benefits of cyclical policies: ceteris paribus, an increase in magnitude of the fiscal policy cycle significantly affects the political rating of an incumbent governor and the probability of re-election. A $10 \%$ increase in the magnitude of the cycle leads to growth in incumbents' popularity of 3.5\%. We should emphasize that we most probably underestimate the effect of the cycles on chances to get re-elected because of possible endogeneity (discussed in the methodology section) and because we assumed the same mix of fiscal policy instruments for the measure of magnitude across regions. ${ }^{37}$ Cross-terms are insignificant in all regressions, except for the cross-terms of the cycle amplitude with freedom of media and with democracy. They have negative significant coefficients in regressions explaining incumbent's popularity. Thus, as democracy matures and press becomes more

\footnotetext{
${ }^{37}$ Based on the case of the four federal elections in Russia, Treisman and Gimpelson (2001) argued that traditional empirical approach underestimates opportunistic cycles because it considers policy instruments separately, whereas, politicians change them from one election to another depending on political environment. Large samples, however, should allow observing opportunistic cycles in each policy instrument separately despite this underestimation.
} 
independent, voters do not reward politicians as much for engaging in pre-electoral manipulations. $^{38}$

\section{Conclusion}

In this paper we tested for existence of opportunistic political cycles and studied whether voter awareness, maturity of democracy, transparency of government, and learning affect cycles. We also examined if cycles increase governors' chances to get reelected and whether this effect depends on awareness, democracy, and transparency. The monthly regional panel data allowed us to define timing of the cycle more precisely than it has been previously done in the literature.

We found strong evidence that:

1) Opportunistic political cycles in budgetary spending have taken place in Russian regions in the period between 1996 and 2003. Most sizable cyclical changes happen within a month or two away from election date.

2) The magnitude of the cycles decreases with education, urbanization, level of democracy, transparency of the government, and freedom of media as well as over time. Thus, informational symmetries and maturity of democracy are important factors influencing cycles.

3) The scale of pre-electoral manipulations increases popularity of incumbent governors and the probability to get re-elected. Freedom of regional media and the level of regional democracy reduce the positive effect of cycles on chances to get reelected.

We show why previous studies underestimated the cycle: quarterly frequency of data is insufficient: cycles are short-lived. In addition, our evidence is consistent with the

${ }^{38}$ In developed democracies, voters actually punish politicians for unsound fiscal policies. See, for instance, Alesina, Perotti, and Tavares (1998) and Brender (2003). 
view that in a maturing democracy cycles disappear very fast, although, it could be the case that other institutional factors rather than learning reduced cycles in Russia. Over the seven years of Russia’s transition (considered in this paper) cycles became significantly smaller.

Russian democracy is very young. Thus, the presence of cycles itself may be a good piece of news because it confirms that there is some electoral pressure on Russia's governors (there would be no reason for pre-electoral manipulation if re-election of incumbent politicians were certain). Thus, so-called "administrative resource," e.g., the ability to influence vote count, does not completely annihilate political incentives. Yet, we have shown that the optimal political strategy is to accumulate wage arrears in the public sector throughout the term and pay them out close to the election date. This has severe welfare implications in terms of consumption smoothing for the poor part of electorate (targeted by the cycle) since Russia’s financial markets are underdeveloped. If voters learn, however, which is consistent with the evidence, one could hope for increasingly more efficient response of Russian governors to political pressure.

\section{References}

Alesina A., Roubini, N., and Cohen, G. (1997) Political Cycles and the Macroeconomy, MIT Press, Cambridge, MA.

Alesina, A. (1987) "Macroeconomic Policy in a Two-Party System as a Repeated Game," Quarterly Journal of Economics, 102, 651-678.

Alesina, A. and Roubini, N. (1992) "Political Cycles in OECD Economies," Review of Economic Studies, 59(4), 663-688.

Alesina, A. and Sachs, J. (1988) "Political Parties and the Business Cycles in the United States, 1984-1984,” Journal of Money, Credit and Banking, 20, 63-82.

Alesina, A., Perotti, R., and Tavares J. (1998) "The Political Economy of Fiscal Adjustments,” Brookings Papers on Economic Activity, Vol. 1, 197-266. 
Arellano M., and Bond, M. (1991) “Some Tests of Specification for Panel Data: MonteCarlo Evidence and an Application to Employment Equations,” Review of Economic Studies, Volume 58, Issue 2 (Apr.), 277-297.

Berger, H. and Woitek, U. (1997) “Searching for Political Business Cycles in Germany," Public Choice, 91(2), 179-197.

Besley, T. and Case, A. (1995) "Does Political Accountability Affect Economic Policy Choices? Evidence from Gubernatorial Term Limits,” Quarterly Journal of Economics, 110 (3), 769-798.

Block, S. (2001) "Elections, Electoral Competitiveness, and Political Budget Cycles in Developing Countries,” Fletcher School of Law and Diplomacy, Tufts University Working Paper.

Block, S., Ferree, K., and Singh, S. (2001) “Institutions, Electoral Competitiveness, and Political Business Cycles in Nascent Democracies,” Fletcher School of Law and Diplomacy, Tufts University Working Paper.

Brender, A. (2003) “The Effect of Fiscal Performance on Local Government Election Results in Israel: 1989-1998, Journal of Public Economics, Volume 87, Issues 9-10, 1839-2396.

Brender, A. and Drazen, A. (2003) "Where Does the Political Budget Cycle Really Come From?” CEPR Discussion Paper \# 4049.

Cook, R. (1977) “Detection of Influential Observations in Linear Inference,” Journal of Statistical Planning and Inference, 37, 51-68.

Drazen, A. (2000) “The Political Business Cycle After 25 Years,” NBER Macroeconomic Annual, Cambridge, MA: MIT Press.

Drazen, A. and Eslava, A. (2003) “The Political Budget Cycle in Columbia,” working paper, University of Maryland.

Franzese, R. (2002) “Electoral and Partisan Cycles in Economic Policies and Outcomes,” Annual Review of Political Science, 5: 369-421.

Frey, B. (1978) “Politico-economic Models and Cycles,” Journal of Public Economics, 9, 203-220.

Frey, B. and Schneider, F. (1978), “A Model of Politico-economic Behavior in the UK,” The Economic Journal, 88, 243-253. 
Gonzalez, M. (2000) “On Elections, Democracy, and Macroeconomic Policy: Evidence from Mexico,” Working Paper, Department of Economics, Princeton University.

Gonzalez, M. (2002) "Do Changes in Democracy Affect the Political Budget Cycle?

Evidence from Mexico,” Review of Development Economics, 6(2), 204-224.

Hansen, L.P. (1982) "Large Sample Properties of Generalized Method of Moments Estimators,” Econometrica, 50, 1029-1054.

Heckelman, J.C. and Berument, H. (1998), "Political Business Cycles and Endogenous Elections," Southern Economic Journal, 64(4), 987-1000.

Hibbs, D. (1977), "Political Parties and Macroeconomic Policy,” American Political Science Review, 7, 1467-1487.

Kalecki, M. (1943) “Political Aspects of Full Employment,” Political Quarterly, 14, 322331.

Keller, M. and May, A. M. (1984), "The Presidential Political Business Cycle of 1972,” The Journal of Economic History, 44(2), 265-271.

Klein, M. (1996) “Timing Is All: Elections and the Duration of United States Business Cycles,” Journal of Money, Credit and Banking, 28(1), 84-101.

Krueger, A. and Turan, I. (1993) "The Politics and Economics of Turkish Policy Reform in the 1980's," in R. Bates and A. Krueger, eds. Political and Economic Interactions in Economic Policy Reform: Evidence from Eight Countries, Oxford: Basil Blackwell.

Nordhaus, W. (1975) “The Political Business Cycle,” Review of Economic Studies, 42, 169-190.

Persson, T. and Tabellini G. (1990) Macroeconomic Policy, Credibility and Politics, Switzerland: Harwood Academic Publishers.

Persson, T. and Tabellini, G. (2003) "Do Electoral Cycles Differ Across Political Systems?” working paper \# 232, University of Bocconi.

Petrov, N. (2001) Russia's Regions in 1999: an Annual Supplement to "Russia's Political Almanac,” Petrov, Nikolai, Ed., March 2001, 456 pp.

Reid, B.G. (1998) "Endogenous Elections, Electoral Budget Cycles and Canadian Provincial Governments,” Public Choice, 97(1-2), 35-48.

Rogoff, K. (1990) “Equilibrium Political Budget Cycles,” American Economic Review 80, 21-36. 
Rogoff, K. and Sibert, A. (1988), “Elections and macroeconomic policy cycles,” Review of Economic Studies, 55, 1-16.

Schuknecht, L. (1998) "Fiscal Policy Cycles and the Exchange Regime in Developing Countries,” WTO working paper.

Schuknecht, L. (2000) "Fiscal Policy Cycles and Public Expenditure in Developing Countries,” Public Choice, 102(1-2), 115-30.

Shi, M. and Svensson, J. (2002a) “Conditional Political Budget Cycles,” CEPR Discussion Paper \# 3352.

Shi, M. and Svensson, J. (2002b) "Political Business Cycles in Developed and Developing Countries,” working paper.

Treisman, D. and Gimpelson, V. (2001) "Political Business Cycles and Russian Elections, or the Manipulations of "Chudar," British Journal of Political Science, 31(2):225-46.

White, H. (1982) “Instrumental Variables Regression with Independent Observations,” Econometrica, 50, 483-499. 
Table 1. Summary statistics for the constructed measures of the amplitude of the cycles

\begin{tabular}{lcccccc}
\hline \multicolumn{1}{l}{} & Obs. & Mean & Median & S.E. & Min & Max \\
\hline Amplitude of the Cycle in: & & & & & & \\
Total Budget Expenditures & 151 & $0.069 *$ & 0.079 & 0.019 & -0.724 & 0.648 \\
Social Expenditures & 153 & $0.186 *$ & 0.126 & 0.035 & -1.410 & 1.811 \\
Education Expenditures & 151 & $0.082 *$ & 0.078 & 0.017 & -0.591 & 0.508 \\
Expenditures on Culture & 150 & $0.065 *$ & 0.111 & 0.028 & -2.049 & 1.015 \\
Healthcare Expenditures & 150 & $0.083 *$ & 0.115 & 0.024 & -0.668 & 1.155 \\
Media Expenditures & 151 & $0.134 *$ & 0.145 & 0.045 & -2.095 & 1.658 \\
Expenditures on Industry & 146 & $0.194 *$ & 0.255 & 0.064 & -2.018 & 2.454 \\
Ratio of Expenditures to Revenues & 151 & $0.034 *$ & 0.052 & 0.014 & -0.542 & 0.580 \\
Negative of Regional Wage Arrears & 80 & $0.234 *$ & 0.185 & 0.083 & -2.078 & 2.938 \\
Expenditures on Agriculture & 145 & 0.044 & -0.011 & 0.053 & -1.423 & 1.552 \\
Total Budget Revenues & 153 & 0.039 & 0.027 & 0.021 & -0.733 & 0.835 \\
Negative of Tax Revenues & 152 & 0.007 & -0.019 & 0.019 & -0.682 & 1.085 \\
\hline
\end{tabular}

Note: Stars denote mean amplitudes that are significantly different from zero. 


\begin{tabular}{|c|c|c|c|c|c|c|c|c|c|c|c|c|c|c|c|}
\hline & 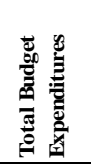 & 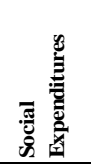 & 总 & 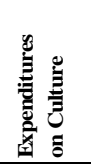 & 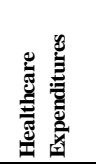 & 兽 & 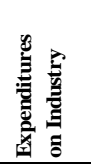 & 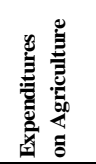 & 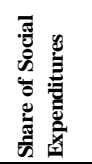 & 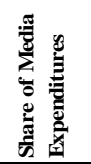 & 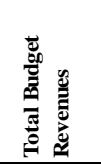 & 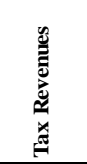 & 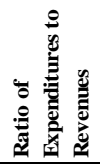 & 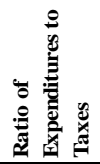 & 常 \\
\hline month -12 & $\begin{array}{l}-0.022 \\
{[0.93]}\end{array}$ & $\begin{array}{c}0.026 \\
{[0.69]}\end{array}$ & $\begin{array}{c}0.016 \\
{[0.66]}\end{array}$ & $\begin{array}{c}0.013 \\
{[0.44]}\end{array}$ & $\begin{array}{c}0.006 \\
{[0.22]}\end{array}$ & $\begin{array}{l}0.048 \\
{[0.93]}\end{array}$ & $\begin{array}{c}-0.032 \\
{[0.34]}\end{array}$ & $\begin{array}{c}0.018 \\
{[0.20]}\end{array}$ & $\begin{array}{c}0.064 * \\
{[1.88]}\end{array}$ & $\begin{array}{l}0.066 \\
{[1.41]}\end{array}$ & $\begin{array}{l}0.050 * \\
{[1.87]}\end{array}$ & $\begin{array}{l}0.022 \\
{[1.02]}\end{array}$ & $\begin{array}{c}-0.047^{* *} \\
{[2.50]}\end{array}$ & $\begin{array}{l}-0.015 \\
{[0.69]}\end{array}$ & $\begin{array}{c}0.02 \\
{[0.28]}\end{array}$ \\
\hline month -11 & $\begin{array}{r}-0.035 \\
{[1.44]}\end{array}$ & $\begin{array}{c}0.011 \\
{[0.31]}\end{array}$ & $\begin{array}{c}-0.039 * \\
{[1.67]}\end{array}$ & $\begin{array}{l}-0.03 \\
{[1.04]}\end{array}$ & $\begin{array}{l}-0.024 \\
{[0.96]}\end{array}$ & $\begin{array}{l}0.007 \\
{[0.13]}\end{array}$ & $\begin{array}{l}-0.052 \\
{[0.55]}\end{array}$ & $\begin{array}{l}-0.121 \\
{[1.42]}\end{array}$ & $\begin{array}{c}0.019 \\
{[0.55]}\end{array}$ & $\begin{array}{c}0.03 \\
{[0.64]}\end{array}$ & $\begin{array}{l}-0.018 \\
{[0.69]}\end{array}$ & $\begin{array}{c}-0.047^{* *} \\
{[2.15]}\end{array}$ & $\begin{array}{r}-0.027 \\
{[1.44]}\end{array}$ & $\begin{array}{l}-0.009 \\
{[0.39]}\end{array}$ & $\begin{array}{l}-0.032 \\
{[0.44]}\end{array}$ \\
\hline month -10 & $\begin{array}{l}0.003 \\
{[0.13]}\end{array}$ & $\begin{array}{l}0.026 \\
{[0.70]}\end{array}$ & $\begin{array}{l}0.039^{*} \\
{[1.69]}\end{array}$ & $\begin{array}{l}0.025 \\
{[0.87]}\end{array}$ & $\begin{array}{l}0.033 \\
{[1.32]}\end{array}$ & $\begin{array}{c}0.133^{* * *} \\
{[2.60]}\end{array}$ & $\begin{array}{l}-0.018 \\
{[0.19]}\end{array}$ & $\begin{array}{c}-0.161^{*} \\
{[1.91]}\end{array}$ & $\begin{array}{c}0.032 \\
{[0.94]}\end{array}$ & $\begin{array}{l}0.111^{* *} \\
{[2.38]}\end{array}$ & $\begin{array}{l}0.003 \\
{[0.13]}\end{array}$ & $\begin{array}{c}-0.024 \\
{[1.11]}\end{array}$ & $\begin{array}{l}-0.004 \\
{[0.23]}\end{array}$ & $\begin{array}{l}0.037^{*} \\
{[1.67]}\end{array}$ & $\begin{array}{l}0.013 \\
{[0.18]}\end{array}$ \\
\hline month -9 & $\begin{array}{l}0.037 \\
{[1.53]}\end{array}$ & $\begin{array}{c}0.062 * \\
{[169]}\end{array}$ & $\begin{array}{l}0.024 \\
{[1.04]}\end{array}$ & $\begin{array}{l}0.042 \\
{[1.44]}\end{array}$ & $\begin{array}{c}0.03 \\
{[1.20]}\end{array}$ & $\begin{array}{l}0.046 \\
{[0.89]}\end{array}$ & $\begin{array}{l}0.187 * \\
{[1.93]}\end{array}$ & $\begin{array}{c}0.03 \\
{[0.36]}\end{array}$ & $\begin{array}{r}-0.01 \\
{[0.31]}\end{array}$ & $\begin{array}{l}0.032 \\
{[0.69]}\end{array}$ & $\begin{array}{c}0.02 \\
{[0.82]}\end{array}$ & $\begin{array}{l}0.005 \\
{[0.24]}\end{array}$ & $\begin{array}{l}0.003 \\
{[0.15]}\end{array}$ & $\begin{array}{l}0.032 \\
{[1.41]}\end{array}$ & $\begin{array}{l}0.055 \\
{[0.87]}\end{array}$ \\
\hline month -8 & $\begin{array}{c}0.014 \\
{[0.57]}\end{array}$ & $\begin{array}{c}0.027 \\
{[0.73]}\end{array}$ & $\begin{array}{l}-0.001 \\
{[0.04]}\end{array}$ & $\begin{array}{c}0.017 \\
{[0.59]}\end{array}$ & $\begin{array}{l}0.027 \\
{[1.10]}\end{array}$ & $\begin{array}{l}-0.012 \\
{[0.24]}\end{array}$ & $\begin{array}{l}0.042 \\
{[0.45]}\end{array}$ & $\begin{array}{c}-0.184^{* *} \\
{[2.21]}\end{array}$ & $\begin{array}{l}0.055 \\
{[1.61]}\end{array}$ & $\begin{array}{l}-0.014 \\
{[0.29]}\end{array}$ & $\begin{array}{r}-0.037 \\
{[1.48]}\end{array}$ & $\begin{array}{l}0.003 \\
{[0.14]}\end{array}$ & $\begin{array}{c}0.013 \\
{[0.75]}\end{array}$ & $\begin{array}{c}-0.007 \\
{[0.31]}\end{array}$ & $\begin{array}{l}-0.068 \\
{[1.09]}\end{array}$ \\
\hline month -7 & $\begin{array}{l}0.035 \\
{[1.46]}\end{array}$ & $\begin{array}{c}-0.03 \\
{[0.86]}\end{array}$ & $\begin{array}{l}0.003 \\
{[0.12]}\end{array}$ & $\begin{array}{c}-0.02 \\
{[0.75]}\end{array}$ & $\begin{array}{l}0.007 \\
{[0.31]}\end{array}$ & $\begin{array}{l}0.006 \\
{[0.12]}\end{array}$ & $\begin{array}{c}-0.062 \\
{[0.72]}\end{array}$ & $\begin{array}{c}-0.125 \\
{[1.61]}\end{array}$ & $\begin{array}{c}-0.02 \\
{[0.59]}\end{array}$ & $\begin{array}{l}-0.027 \\
{[0.59]}\end{array}$ & $\begin{array}{c}0 \\
{[0.01]}\end{array}$ & $\begin{array}{l}-0.017 \\
{[0.81]}\end{array}$ & $\begin{array}{l}0.005 \\
{[0.29]}\end{array}$ & $\begin{array}{l}0.037 \\
{[1.63]}\end{array}$ & $\begin{array}{l}-0.014 \\
{[0.22]}\end{array}$ \\
\hline month -6 & $\begin{array}{c}0.013 \\
{[0.54]}\end{array}$ & $\begin{array}{l}-0.025 \\
{[0.73]}\end{array}$ & $\begin{array}{l}0.033 \\
{[1.54]}\end{array}$ & $\begin{array}{l}0.033 \\
{[1.23]}\end{array}$ & $\begin{array}{l}0.026 \\
{[1.15]}\end{array}$ & $\begin{array}{r}-0.079 \\
{[1.56]}\end{array}$ & $\begin{array}{l}0.005 \\
{[0.06]}\end{array}$ & $\begin{array}{l}-0.013 \\
{[0.17]}\end{array}$ & $\begin{array}{c}-0.022 \\
{[0.66]}\end{array}$ & $\begin{array}{c}-0.059 \\
{[1.31]}\end{array}$ & $\begin{array}{l}-0.019 \\
{[0.83]}\end{array}$ & $\begin{array}{l}-0.004 \\
{[0.22]}\end{array}$ & $\begin{array}{c}0.032 * \\
{[1.81]}\end{array}$ & $\begin{array}{c}0 \\
{[0.02]}\end{array}$ & $\begin{array}{l}-0.042 \\
{[0.68]}\end{array}$ \\
\hline month -5 & $\begin{array}{l}0.004 \\
{[0.19]}\end{array}$ & $\begin{array}{l}0.063^{*} \\
{[1.87]}\end{array}$ & $\begin{array}{l}0.025 \\
{[1.16]}\end{array}$ & $\begin{array}{l}-0.028 \\
{[1.06]}\end{array}$ & $\begin{array}{l}0.003 \\
{[0.13]}\end{array}$ & $\begin{array}{l}-0.043 \\
{[0.85]}\end{array}$ & $\begin{array}{r}-0.027 \\
{[0.31]}\end{array}$ & $\begin{array}{l}0.067 \\
{[0.91]}\end{array}$ & $\begin{array}{l}0.042 \\
{[1.27]}\end{array}$ & $\begin{array}{l}-0.017 \\
{[0.39]}\end{array}$ & $\begin{array}{l}0.024 \\
{[1.10]}\end{array}$ & $\begin{array}{c}0.019 \\
{[1.00]}\end{array}$ & $\begin{array}{l}-0.007 \\
{[0.42]}\end{array}$ & $\begin{array}{l}0.004 \\
{[0.17]}\end{array}$ & $\begin{array}{l}0.105^{*} \\
{[1.70]}\end{array}$ \\
\hline month -4 & $\begin{array}{r}0.001 \\
{[0.05]}\end{array}$ & $\begin{array}{l}0.071^{* *} \\
{[2.14]}\end{array}$ & $\begin{array}{l}-0.018 \\
{[0.88]}\end{array}$ & $\begin{array}{c}-0.038 \\
{[1.49]}\end{array}$ & $\begin{array}{l}-0.03 \\
{[1.37]}\end{array}$ & $\begin{array}{l}0.039 \\
{[0.79]}\end{array}$ & $\begin{array}{r}0.081 \\
{[0.94]}\end{array}$ & $\begin{array}{l}-0.041 \\
{[0.58]}\end{array}$ & $\begin{array}{l}0.038 \\
{[1.15]}\end{array}$ & $\begin{array}{l}0.033 \\
{[0.76]}\end{array}$ & $\begin{array}{c}-0.027 \\
{[1.22]}\end{array}$ & $\begin{array}{l}0.008 \\
{[0.39]}\end{array}$ & $\begin{array}{c}0.015 \\
{[0.89]}\end{array}$ & $\begin{array}{l}0.013 \\
{[0.61]}\end{array}$ & $\begin{array}{l}-0.007 \\
{[0.12]}\end{array}$ \\
\hline month -3 & $\begin{array}{l}0.050 \text { ** } \\
{[2.31]}\end{array}$ & $\begin{array}{l}0.052 \\
{[1.55]}\end{array}$ & $\begin{array}{l}-0.011 \\
{[0.52]}\end{array}$ & $\begin{array}{l}0.002 \\
{[0.06]}\end{array}$ & $\begin{array}{c}0.017 \\
{[0.78]}\end{array}$ & $\begin{array}{c}0.028 \\
{[0.59]}\end{array}$ & $\begin{array}{c}-0.03 \\
{[0.34]}\end{array}$ & $\begin{array}{l}-0.019 \\
{[0.26]}\end{array}$ & $\begin{array}{r}-0.006 \\
{[0.21]}\end{array}$ & $\begin{array}{l}0.019 \\
{[0.46]}\end{array}$ & $\begin{array}{l}0.023 \\
{[1.06]}\end{array}$ & $\begin{array}{c}0.056 * * * \\
{[2.91]}\end{array}$ & $\begin{array}{l}0.039 * * \\
{[2.44]}\end{array}$ & $\begin{array}{l}0.005 \\
{[0.27]}\end{array}$ & $\begin{array}{l}-0.027 \\
{[0.45]}\end{array}$ \\
\hline month -2 & $\begin{array}{l}0.008 \\
{[0.36]}\end{array}$ & $\begin{array}{c}0.102 * * \\
{[3.09]}\end{array}$ & $\begin{array}{c}0.018 \\
{[0.85]}\end{array}$ & $\begin{array}{c}0.014 \\
{[0.54]}\end{array}$ & $\begin{array}{l}0.050^{* *} \\
{[2.25]}\end{array}$ & $\begin{array}{c}0.203^{*+*} \\
{[4.34]}\end{array}$ & $\begin{array}{l}0.145^{*} \\
{[1.70]}\end{array}$ & $\begin{array}{c}0.01 \\
{[0.13]}\end{array}$ & $\begin{array}{c}0.080^{* * *} \\
{[2.62]}\end{array}$ & $\begin{array}{c}0.165 * * * \\
{[4.02]}\end{array}$ & $\begin{array}{l}0.017 \\
{[0.76]}\end{array}$ & $\begin{array}{l}0.029 \\
{[1.54]}\end{array}$ & $\begin{array}{c}0.007 \\
{[0.47]}\end{array}$ & $\begin{array}{l}-0.015 \\
{[0.76]}\end{array}$ & $\begin{array}{l}0.046 \\
{[0.79]}\end{array}$ \\
\hline month -1 & $\begin{array}{c}0.094^{*} \\
{[4.25]}\end{array}$ & $\begin{array}{c}0.266 * * \\
{[7.74]}\end{array}$ & $\begin{array}{c}0.127 * * * \\
{[5.86]}\end{array}$ & $\begin{array}{c}0.138^{* * * *} \\
{[5.10]}\end{array}$ & $\begin{array}{l}0.110^{* * * *} \\
{[4.76]}\end{array}$ & $\begin{array}{l}0.114^{* *} \\
{[2.36]}\end{array}$ & $\begin{array}{c}0.258^{\text {**** }} \\
{[2.89]}\end{array}$ & $\begin{array}{l}0.045 \\
{[0.59]}\end{array}$ & $\begin{array}{l}0.135^{* * *} \\
{[4.30]}\end{array}$ & $\begin{array}{l}-0.003 \\
{[0.06]}\end{array}$ & $\begin{array}{c}0.050 * \\
{[2.20]}\end{array}$ & $\begin{array}{l}0.008 \\
{[0.42]}\end{array}$ & $\begin{array}{c}0.046 \text { **ak } \\
{[2.84]}\end{array}$ & $\begin{array}{c}0.099 * * * \\
{[4.78]}\end{array}$ & $\begin{array}{c}0.195^{\text {**+* }} \\
{[3.12]}\end{array}$ \\
\hline $\begin{array}{l}\text { month } 0 \text { - } \\
\text { elections }\end{array}$ & $\begin{array}{c}-0.088^{*+1+4} \\
{[4.07]}\end{array}$ & $\begin{array}{l}0.032 \\
{[0.94]}\end{array}$ & $\begin{array}{c}-0.067 \text { * } \\
{[3.12]}\end{array}$ & $\begin{array}{c}-0.073^{*+*} \\
{[2.76]}\end{array}$ & $\begin{array}{c}-0.066^{*+1 *} \\
{[2.91]}\end{array}$ & $\begin{array}{c}-0.152^{* * * *} \\
{[3.19]}\end{array}$ & $\begin{array}{l}-0.121 \\
{[1.40]}\end{array}$ & $\begin{array}{l}-0.068 \\
{[0.88]}\end{array}$ & $\begin{array}{c}0.092 * * * \\
{[2.99]}\end{array}$ & $\begin{array}{c}-0.095 * * \\
{[2.27]}\end{array}$ & $\begin{array}{c}-0.084 * * * \\
{[3.74]}\end{array}$ & $\begin{array}{r}-0.032 \\
{[1.59]}\end{array}$ & $\begin{array}{c}0.02 \\
{[1.22]}\end{array}$ & $\begin{array}{l}-0.021 \\
{[1.05]}\end{array}$ & $\begin{array}{c}-0.182^{\text {twe }} \\
{[2.83]}\end{array}$ \\
\hline month +1 & $\begin{array}{c}-0.053^{* *} \\
{[2.44]}\end{array}$ & $\begin{array}{c}-0.077^{* *} \\
{[2.28]}\end{array}$ & $\begin{array}{c}-0.032 \\
{[1.49]}\end{array}$ & $\begin{array}{c}-0.115^{* * * *} \\
{[4.44]}\end{array}$ & $\begin{array}{c}-0.042 * \\
{[1.85]}\end{array}$ & $\begin{array}{c}-0.104^{* *} \\
{[2.20]}\end{array}$ & $\begin{array}{c}-0.176 * * \\
{[2.06]}\end{array}$ & $\begin{array}{l}-0.055 \\
{[0.73]}\end{array}$ & $\begin{array}{l}-0.028 \\
{[0.92]}\end{array}$ & $\begin{array}{c}-0.086^{* *} \\
{[2.05]}\end{array}$ & $\begin{array}{c}-0.058^{* * *} \\
{[2.59]}\end{array}$ & $\begin{array}{c}-0.043^{* *} \\
{[2.20]}\end{array}$ & $\begin{array}{l}-0.008 \\
{[0.47]}\end{array}$ & $\begin{array}{l}-0.031 \\
{[1.52]}\end{array}$ & $\begin{array}{l}-0.026 \\
{[0.39]}\end{array}$ \\
\hline month +2 & $\begin{array}{c}-0.025 \\
{[1.17]}\end{array}$ & $\begin{array}{l}-0.023 \\
{[0.68]}\end{array}$ & $\begin{array}{c}-0.005 \\
{[0.24]}\end{array}$ & $\begin{array}{l}-0.021 \\
{[0.81]}\end{array}$ & $\begin{array}{l}-0.031 \\
{[1.40]}\end{array}$ & $\begin{array}{r}-0.043 \\
{[0.91]}\end{array}$ & $\begin{array}{c}-0.049 \\
{[0.57]}\end{array}$ & $\begin{array}{c}-0.205^{* * *} \\
{[2.74]}\end{array}$ & $\begin{array}{c}0.002 \\
{[0.07]}\end{array}$ & $\begin{array}{c}-0.055 \\
{[1.32]}\end{array}$ & $\begin{array}{l}-0.008 \\
{[0.37]}\end{array}$ & $\begin{array}{c}-0.024 \\
{[1.25]}\end{array}$ & $\begin{array}{c}-0.007 \\
{[0.41]}\end{array}$ & $\begin{array}{l}-0.009 \\
{[0.46]}\end{array}$ & $\begin{array}{l}0.044 \\
{[0.67]}\end{array}$ \\
\hline month +3 & $\begin{array}{l}0.024 \\
{[1.14]}\end{array}$ & $\begin{array}{l}0.046 \\
{[1.38]}\end{array}$ & $\begin{array}{c}-0.004 \\
{[0.18]}\end{array}$ & $\begin{array}{l}-0.04 \\
{[1.56]}\end{array}$ & $\begin{array}{c}0.012 \\
{[0.52]}\end{array}$ & $\begin{array}{c}-0.052 \\
{[1.11]}\end{array}$ & $\begin{array}{l}0.092 \\
{[1.10]}\end{array}$ & $\begin{array}{l}-0.037 \\
{[0.50]}\end{array}$ & $\begin{array}{c}0.019 \\
{[0.65]}\end{array}$ & $\begin{array}{l}-0.06 \\
{[1.46]}\end{array}$ & $\begin{array}{l}0.016 \\
{[0.70]}\end{array}$ & $\begin{array}{l}-0.017 \\
{[0.89]}\end{array}$ & $\begin{array}{l}0.002 \\
{[0.10]}\end{array}$ & $\begin{array}{l}0.036 * \\
{[1.80]}\end{array}$ & $\begin{array}{l}0.004 \\
{[0.06]}\end{array}$ \\
\hline month +4 & $\begin{array}{c}-0.025 \\
{[1.16]}\end{array}$ & $\begin{array}{l}-0.002 \\
{[0.05]}\end{array}$ & $\begin{array}{l}-0.008 \\
{[0.39]}\end{array}$ & $\begin{array}{l}-0.031 \\
{[1.22]}\end{array}$ & $\begin{array}{l}0.003 \\
{[0.14]}\end{array}$ & $\begin{array}{r}-0.048 \\
{[1.03]}\end{array}$ & $\begin{array}{c}0.03 \\
{[0.36]}\end{array}$ & $\begin{array}{l}-0.051 \\
{[0.70]}\end{array}$ & $\begin{array}{c}0.002 \\
{[0.08]}\end{array}$ & $\begin{array}{l}0.013 \\
{[0.31]}\end{array}$ & $\begin{array}{c}-0.028 \\
{[1.27]}\end{array}$ & $\begin{array}{c}0.018 \\
{[0.93]}\end{array}$ & $\begin{array}{l}0.019 \\
{[1.20]}\end{array}$ & $\begin{array}{l}-0.02 \\
{[1.01]}\end{array}$ & $\begin{array}{c}-0.176^{*+1} \\
{[2.62]}\end{array}$ \\
\hline month +5 & $\begin{array}{c}0.03 \\
{[1.42]}\end{array}$ & $\begin{array}{c}0.053^{*} \\
{[1.65]}\end{array}$ & $\begin{array}{c}0.035^{*} \\
{[1.72]}\end{array}$ & $\begin{array}{l}-0.011 \\
{[0.42]}\end{array}$ & $\begin{array}{c}0.018 \\
{[0.84]}\end{array}$ & $\begin{array}{c}0.02 \\
{[0.43]}\end{array}$ & $\begin{array}{l}-0.031 \\
{[0.38]}\end{array}$ & $\begin{array}{l}-0.018 \\
{[0.25]}\end{array}$ & $\begin{array}{c}0.026 \\
{[0.86]}\end{array}$ & $\begin{array}{l}0.018 \\
{[0.45]}\end{array}$ & $\begin{array}{r}-0.035 \\
{[1.60]}\end{array}$ & $\begin{array}{c}0 \\
{[0.02]}\end{array}$ & $\begin{array}{l}0.040^{* *} \\
{[2.49]}\end{array}$ & $\begin{array}{c}0.017 \\
{[0.85]}\end{array}$ & $\begin{array}{r}-0.084 \\
{[1.27]}\end{array}$ \\
\hline month +6 & $\begin{array}{l}-0.001 \\
{[0.04]}\end{array}$ & $\begin{array}{l}0.065^{* *} \\
{[2.03]}\end{array}$ & $\begin{array}{c}0.011 \\
{[0.52]}\end{array}$ & $\begin{array}{c}-0.047^{*} \\
{[1.91]}\end{array}$ & $\begin{array}{l}-0.023 \\
{[1.08]}\end{array}$ & $\begin{array}{c}-0.053 \\
{[1.14]}\end{array}$ & $\begin{array}{l}0.017 \\
{[0.21]}\end{array}$ & $\begin{array}{l}0.049 \\
{[0.69]}\end{array}$ & $\begin{array}{c}0.052 * \\
{[1.71]}\end{array}$ & $\begin{array}{l}-0.065 \\
{[1.57]}\end{array}$ & $\begin{array}{c}-0.029 \\
{[1.32]}\end{array}$ & $\begin{array}{l}0.002 \\
{[0.09]}\end{array}$ & $\begin{array}{l}0.037 * * \\
{[2.29]}\end{array}$ & $\begin{array}{l}-0.007 \\
{[0.36]}\end{array}$ & $\begin{array}{c}0 \\
{[0.00]}\end{array}$ \\
\hline month +7 & $\begin{array}{l}0.006 \\
{[0.31]}\end{array}$ & $\begin{array}{l}-0.024 \\
{[0.76]}\end{array}$ & $\begin{array}{l}0.006 \\
{[0.30]}\end{array}$ & $\begin{array}{l}-0.021 \\
{[0.85]}\end{array}$ & $\begin{array}{c}0.016 \\
{[0.73]}\end{array}$ & $\begin{array}{r}-0.007 \\
{[0.15]}\end{array}$ & $\begin{array}{c}-0.053 \\
{[0.65]}\end{array}$ & $\begin{array}{l}-0.038 \\
{[0.55]}\end{array}$ & $\begin{array}{l}-0.013 \\
{[0.42]}\end{array}$ & $\begin{array}{l}0.008 \\
{[0.19]}\end{array}$ & $\begin{array}{l}0.009 \\
{[0.43]}\end{array}$ & $\begin{array}{l}0.031^{*} \\
{[1.68]}\end{array}$ & $\begin{array}{l}0.005 \\
{[0.31]}\end{array}$ & $\begin{array}{l}-0.006 \\
{[0.30]}\end{array}$ & $\begin{array}{c}-0.03 \\
{[0.49]}\end{array}$ \\
\hline month +8 & $\begin{array}{l}0.004 \\
{[0.18]}\end{array}$ & $\begin{array}{l}0.025 \\
{[0.78]}\end{array}$ & $\begin{array}{l}0.002 \\
{[0.08]}\end{array}$ & $\begin{array}{l}-0.038 \\
{[1.50]}\end{array}$ & $\begin{array}{l}-0.009 \\
{[0.40]}\end{array}$ & $\begin{array}{l}-0.017 \\
{[0.36]}\end{array}$ & $\begin{array}{l}0.082 \\
{[1.01]}\end{array}$ & $\begin{array}{c}-0.05 \\
{[0.70]}\end{array}$ & $\begin{array}{l}0.019 \\
{[0.61]}\end{array}$ & $\begin{array}{l}-0.052 \\
{[1.25]}\end{array}$ & $\begin{array}{c}-0.024 \\
{[1.11]}\end{array}$ & $\begin{array}{c}-0.008 \\
{[0.41]}\end{array}$ & $\begin{array}{c}0.02 \\
{[1.25]}\end{array}$ & $\begin{array}{l}0.023 \\
{[1.18]}\end{array}$ & $\begin{array}{l}0.059 \\
{[1.00]}\end{array}$ \\
\hline month +9 & $\begin{array}{l}-0.015 \\
{[0.73]}\end{array}$ & $\begin{array}{l}0.007 \\
{[0.22]}\end{array}$ & $\begin{array}{c}-0.004 \\
{[0.19]}\end{array}$ & $\begin{array}{c}-0.038 \\
{[1.51]}\end{array}$ & $\begin{array}{l}-0.015 \\
{[0.70]}\end{array}$ & $\begin{array}{l}0.062 \\
{[1.34]}\end{array}$ & $\begin{array}{l}-0.025 \\
{[0.30]}\end{array}$ & $\begin{array}{l}0.001 \\
{[0.01]}\end{array}$ & $\begin{array}{c}0.013 \\
{[0.44]}\end{array}$ & $\begin{array}{l}0.056 \\
{[1.37]}\end{array}$ & $\begin{array}{l}-0.014 \\
{[0.63]}\end{array}$ & $\begin{array}{l}0.005 \\
{[0.25]}\end{array}$ & $\begin{array}{c}-0.007 \\
{[0.46]}\end{array}$ & $\begin{array}{l}-0.016 \\
{[0.80]}\end{array}$ & $\begin{array}{l}-0.04 \\
{[0.67]}\end{array}$ \\
\hline month +10 & $\begin{array}{l}0.002 \\
{[0.11]}\end{array}$ & $\begin{array}{c}0.051 \\
{[1.58]}\end{array}$ & $\begin{array}{l}-0.011 \\
{[0.53]}\end{array}$ & $\begin{array}{l}0.025 \\
{[1.00]}\end{array}$ & $\begin{array}{l}-0.011 \\
{[0.50]}\end{array}$ & $\begin{array}{l}0.009 \\
{[0.20]}\end{array}$ & $\begin{array}{l}0.015 \\
{[0.18]}\end{array}$ & $\begin{array}{c}0.026 \\
{[0.35]}\end{array}$ & $\begin{array}{l}0.035 \\
{[1.19]}\end{array}$ & $\begin{array}{l}-0.009 \\
{[0.22]}\end{array}$ & $\begin{array}{c}-0.026 \\
{[1.19]}\end{array}$ & $\begin{array}{r}-0.023 \\
{[1.22]}\end{array}$ & $\begin{array}{l}0.027 * \\
{[1.70]}\end{array}$ & $\begin{array}{c}0.011 \\
{[0.57]}\end{array}$ & $\begin{array}{l}0.028 \\
{[0.49]}\end{array}$ \\
\hline month +11 & $\begin{array}{c}0.02 \\
{[0.98]}\end{array}$ & $\begin{array}{l}0.035 \\
{[1.09]}\end{array}$ & $\begin{array}{c}0.013 \\
{[0.66]}\end{array}$ & $\begin{array}{c}0.076^{* * * *} \\
{[3.03]}\end{array}$ & $\begin{array}{l}0.007 \\
{[0.31]}\end{array}$ & $\begin{array}{c}-0.046 \\
{[1.01]}\end{array}$ & $\begin{array}{l}-0.116 \\
{[1.37]}\end{array}$ & $\begin{array}{l}0.036 \\
{[0.51]}\end{array}$ & $\begin{array}{c}0.018 \\
{[0.63]}\end{array}$ & $\begin{array}{l}0.025 \\
{[0.62]}\end{array}$ & $\begin{array}{l}0.023 \\
{[1.07]}\end{array}$ & $\begin{array}{l}0.028 \\
{[1.49]}\end{array}$ & $\begin{array}{c}0.011 \\
{[0.74]}\end{array}$ & $\begin{array}{c}0.01 \\
{[0.51]}\end{array}$ & $\begin{array}{l}-0.071 \\
{[1.24]}\end{array}$ \\
\hline month +12 & $\begin{array}{l}-0.015 \\
{[0.71]}\end{array}$ & $\begin{array}{l}-0.011 \\
{[0.34]}\end{array}$ & $\begin{array}{l}0.028 \\
{[1.38]}\end{array}$ & $\begin{array}{l}-0.001 \\
{[0.05]}\end{array}$ & $\begin{array}{c}0.006 \\
{[0.26]}\end{array}$ & $\begin{array}{l}-0.016 \\
{[0.35]}\end{array}$ & $\begin{array}{l}-0.019 \\
{[0.23]}\end{array}$ & $\begin{array}{c}0.02 \\
{[0.27]}\end{array}$ & $\begin{array}{l}-0.007 \\
{[0.25]}\end{array}$ & $\begin{array}{c}0.04 \\
{[0.98]}\end{array}$ & $\begin{array}{l}-0.015 \\
{[0.70]}\end{array}$ & $\begin{array}{l}0.031 \\
{[1.62]}\end{array}$ & $\begin{array}{l}0.005 \\
{[0.34]}\end{array}$ & $\begin{array}{c}-0.026 \\
{[1.36]}\end{array}$ & $\begin{array}{c}-0.024 \\
{[0.42]}\end{array}$ \\
\hline $\begin{array}{l}\text { Term in } \\
\text { power }\end{array}$ & $\begin{array}{l}0.007 \\
{[0.98]}\end{array}$ & $\begin{array}{l}0.024^{* *} \\
{[2.23]}\end{array}$ & $\begin{array}{l}0.017^{* *} \\
{[2.48]}\end{array}$ & $\begin{array}{c}0.023^{* * * *} \\
{[2.64]}\end{array}$ & $\begin{array}{c}0.032 * * * \\
{[4.37]}\end{array}$ & $\begin{array}{r}-0.025 \\
{[1.57]}\end{array}$ & $\begin{array}{l}-0.006 \\
{[0.20]}\end{array}$ & $\begin{array}{c}0.016 \\
{[0.59]}\end{array}$ & $\begin{array}{c}0.01 \\
{[0.97]}\end{array}$ & $\begin{array}{l}-0.019 \\
{[1.36]}\end{array}$ & $\begin{array}{c}0.018 * * \\
{[2.31]}\end{array}$ & $\begin{array}{l}0.004 \\
{[0.58]}\end{array}$ & $\begin{array}{l}-0.014^{* *} \\
{[2.40]}\end{array}$ & $\begin{array}{l}-0.001 \\
{[0.13]}\end{array}$ & $\begin{array}{l}-0.006 \\
{[0.24]}\end{array}$ \\
\hline Left & $\begin{array}{c}0.024 \\
{[0.67]}\end{array}$ & $\begin{array}{l}-0.029 \\
{[0.60]}\end{array}$ & $\begin{array}{l}0.036 \\
{[1.19]}\end{array}$ & $\begin{array}{c}0.021 \\
{[0.56]}\end{array}$ & $\begin{array}{c}0.011 \\
{[0.33]}\end{array}$ & $\begin{array}{l}-0.052 \\
{[0.65]}\end{array}$ & $\begin{array}{c}0.021 \\
{[0.16]}\end{array}$ & $\begin{array}{c}0.12 \\
{[1.14]}\end{array}$ & $\begin{array}{c}-0.026 \\
{[0.51]}\end{array}$ & $\begin{array}{c}-0.064 \\
{[0.91]}\end{array}$ & $\begin{array}{l}0.041 \\
{[1.27]}\end{array}$ & $\begin{array}{c}0.072 * * \\
{[2.51]}\end{array}$ & $\begin{array}{c}-0.039 \\
{[1.48]}\end{array}$ & $\begin{array}{c}-0.056 \\
{[1.64]}\end{array}$ & $\begin{array}{c}0.147 \\
{[0.96]}\end{array}$ \\
\hline Lag -1 & $\begin{array}{l}0.191^{* * * *} \\
{[15.60]}\end{array}$ & $\begin{array}{c}0.198^{* * *} \\
{[16.45]}\end{array}$ & $\begin{array}{l}0.115^{* * * *} \\
{[9.48]}\end{array}$ & $\begin{array}{c}0.185^{* * *} \\
{[15.17]}\end{array}$ & $\begin{array}{c}0.183^{* * * *} \\
{[15.08]}\end{array}$ & $\begin{array}{l}0.128^{* * * *} \\
{[10.39]}\end{array}$ & $\begin{array}{l}0.300^{* * * *} \\
{[22.84]}\end{array}$ & $\begin{array}{c}0.166^{* * * *} \\
{[12.43]}\end{array}$ & $\begin{array}{c}0.203^{* * *} \\
{[16.15]}\end{array}$ & $\begin{array}{c}0.107^{*+* k} \\
{[8.34]}\end{array}$ & $\begin{array}{l}0.210^{* * *} \\
{[16.93]}\end{array}$ & $\begin{array}{l}0.217^{* * * *} \\
{[17.90]}\end{array}$ & $\begin{array}{l}-0.02 \\
{[1.50]}\end{array}$ & $\begin{array}{l}0.133^{* * *} \\
{[10.48]}\end{array}$ & $\begin{array}{l}0.160^{*+*} \\
{[10.56]}\end{array}$ \\
\hline Lag -2 & $\begin{array}{l}0.111^{* * *} \\
{[9.08]}\end{array}$ & $\begin{array}{l}0.190 * * * \\
{[15.52]}\end{array}$ & $\begin{array}{c}0.091^{*+*} \\
{[7.51]}\end{array}$ & $\begin{array}{l}0.122 * * * \\
{[9.92]}\end{array}$ & $\begin{array}{c}0.104 * * * \\
{[8.49]}\end{array}$ & $\begin{array}{c}0.075^{* * *} \\
{[6.06]}\end{array}$ & $\begin{array}{c}0.139^{* * *} \\
{[10.20]}\end{array}$ & $\begin{array}{c}0.089^{* * * k} \\
{[6.52]}\end{array}$ & $\begin{array}{c}0.152^{* * *} \\
{[11.91]}\end{array}$ & $\begin{array}{c}0.086 \text { * } \\
{[6.77]}\end{array}$ & $\begin{array}{l}0.161^{* * *} \\
{[12.92]}\end{array}$ & $\begin{array}{l}0.163^{* * * *} \\
{[13.45]}\end{array}$ & $\begin{array}{c}0.075^{* * * k} \\
{[5.64]}\end{array}$ & $\begin{array}{l}0.127^{* * *} \\
{[10.08]}\end{array}$ & $\begin{array}{c}0.138^{\text {**t* }} \\
{[9.29]}\end{array}$ \\
\hline Lag - & $\begin{array}{l}0.154^{* * * *} \\
{[12.59]}\end{array}$ & $\begin{array}{l}0.11^{+* * *} \\
{[9.15]}\end{array}$ & $\begin{array}{l}0.131^{* * * *} \\
{[10.88]}\end{array}$ & $\begin{array}{l}0.118 * * \\
{[9.66]}\end{array}$ & $\begin{array}{c}0.125^{* * * *} \\
{[10.26]}\end{array}$ & $\begin{array}{c}0.104^{* * * *} \\
{[8.43]}\end{array}$ & $\begin{array}{c}0.089^{*+1 \%} \\
{[6.58]}\end{array}$ & $\begin{array}{c}0.109^{*+* *} \\
{[8.11]}\end{array}$ & $\begin{array}{l}0.132^{* * * *} \\
{[10.34]}\end{array}$ & $\begin{array}{c}0.099 * * \\
{[7.76]}\end{array}$ & $\begin{array}{l}0.152 * * \\
{[12.23]}\end{array}$ & $\begin{array}{c}0.225 * * * \\
{[18.78]}\end{array}$ & $\begin{array}{c}0.073 \text { *** } \\
{[5.46]}\end{array}$ & $\begin{array}{c}0.122 * * * \\
{[9.82]}\end{array}$ & $\begin{array}{l}0.113^{* * * *} \\
{[7.89]}\end{array}$ \\
\hline Lag -4 & $\begin{array}{l}0.124^{* * *} \\
{[10.29]}\end{array}$ & $\begin{array}{c}0.097 \text { * } \\
{[8.25]}\end{array}$ & $\begin{array}{c}0.073^{* * *} \\
{[6.20]}\end{array}$ & $\begin{array}{c}0.066 * * \\
{[5.63]}\end{array}$ & $\begin{array}{c}0.092 * * \\
{[7.83]}\end{array}$ & $\begin{array}{c}0.073^{* * * *} \\
{[5.95]}\end{array}$ & $\begin{array}{c}0.053^{* * * *} \\
{[4.14]}\end{array}$ & $\begin{array}{c}0.049 * * \\
{[3.70]}\end{array}$ & $\begin{array}{c}0.089 * * \\
{[7.10]}\end{array}$ & $\begin{array}{c}0.074 * * \\
{[5.82]}\end{array}$ & $\begin{array}{l}0.119 \text { **** } \\
{[9.68]}\end{array}$ & $\begin{array}{c}0.050^{\text {w*t* }} \\
{[4.19]}\end{array}$ & $\begin{array}{l}0.005 \\
{[0.35]}\end{array}$ & $\begin{array}{c}0.043^{* * *} \\
{[3.45]}\end{array}$ & $\begin{array}{c}0.075 \text { wat } \\
{[5.23]}\end{array}$ \\
\hline Constant & $\begin{array}{r}-0.027 \\
{[1.48]}\end{array}$ & $\begin{array}{c}-0.083^{\text {*** }} \\
{[3.27]}\end{array}$ & $\begin{array}{l}-0.007 \\
{[0.43]}\end{array}$ & $\begin{array}{c}-0.044^{* *} \\
{[2.21]}\end{array}$ & $\begin{array}{c}-0.056^{* * *} \\
{[3.29]}\end{array}$ & $\begin{array}{c}-0.213^{* * *} \\
{[5.12]}\end{array}$ & $\begin{array}{c}-0.254^{* * * *} \\
{[3.78]}\end{array}$ & $\begin{array}{c}-0.295^{* * *} \\
{[5.18]}\end{array}$ & $\begin{array}{c}-0.065^{* *} \\
{[2.44]}\end{array}$ & $\begin{array}{c}-0.089^{* *} \\
{[2.44]}\end{array}$ & $\begin{array}{c}-0.048^{* * *} \\
{[2.79]}\end{array}$ & $\begin{array}{c}-0.119 * * \\
{[7.74]}\end{array}$ & $\begin{array}{l}0.021 \\
{[1.54]}\end{array}$ & $\begin{array}{c}0.091^{* * *} \\
{[5.25]}\end{array}$ & $\begin{array}{l}0.128^{*} \\
{[1.68]}\end{array}$ \\
\hline Obs. & 6767 & 7004 & 6989 & 6921 & 6966 & 6600 & 5825 & 5775 & 6388 & 6241 & 6498 & 7060 & 5916 & 6437 & 4115 \\
\hline $\begin{array}{l}\text { \# of regions } \\
\mathbf{R}^{2}\end{array}$ & $\begin{array}{c}86 \\
0.163\end{array}$ & $\begin{array}{c}86 \\
0.204\end{array}$ & $\begin{array}{c}86 \\
0.074\end{array}$ & $\begin{array}{c}86 \\
0.123\end{array}$ & $\begin{array}{c}86 \\
0.122\end{array}$ & $\begin{array}{c}86 \\
0.066\end{array}$ & $\begin{array}{c}86 \\
0.203\end{array}$ & $\begin{array}{c}86 \\
0.078\end{array}$ & $\begin{array}{c}86 \\
0.168\end{array}$ & $\begin{array}{c}86 \\
0.058\end{array}$ & $\begin{array}{c}86 \\
0.216\end{array}$ & $\begin{array}{c}86 \\
0.242\end{array}$ & $\begin{array}{c}86 \\
0.02\end{array}$ & $\begin{array}{c}86 \\
0.081\end{array}$ & $\begin{array}{r}86 \\
0.12\end{array}$ \\
\hline
\end{tabular}

Note: All dependent variables are de-trended and in logs. They are measured in real terms per capita. Absolute values of t-statistics are in parentheses. ***, ** and * denote significance at 1, 5 and 10\% level, respectively. Regional Fixed effects included. 
Table 3. Cycles in wages, wage arrears and economic outcomes

\begin{tabular}{|c|c|c|c|c|c|}
\hline & है & 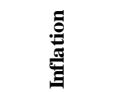 & 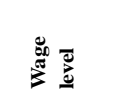 & 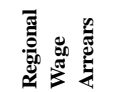 & 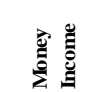 \\
\hline \multirow{2}{*}{$\overline{\text { month }-12}$} & -0.002 & 0.001 & 0.002 & 0.087 & $0.017 * *$ \\
\hline & {$[0.12]$} & [0.55] & [0.38] & {$[0.96]$} & [2.15] \\
\hline \multirow[t]{2}{*}{ month -11} & -0.005 & 0.000 & 0.000 & 0.045 & -0.009 \\
\hline & {$[0.36]$} & [0.15] & [0.07] & {$[0.50]$} & [1.07] \\
\hline \multirow[t]{2}{*}{ month -10} & -0.001 & 0.001 & -0.007 & 0.068 & 0.012 \\
\hline & {$[0.07]$} & {$[0.37]$} & [1.37] & [0.92] & [1.43] \\
\hline \multirow[t]{2}{*}{ month -9} & -0.007 & -0.001 & 0.002 & -0.008 & 0.011 \\
\hline & [0.59] & {$[0.91]$} & [0.34] & {$[0.11]$} & [1.38] \\
\hline \multirow[t]{2}{*}{ month -8} & $-0.031 * *$ & 0.000 & -0.003 & -0.009 & $-0.015 *$ \\
\hline & [2.42] & {$[0.00]$} & [0.56] & [0.12] & [1.83] \\
\hline \multirow[t]{2}{*}{ month -7} & 0.004 & -0.001 & 0.003 & 0.039 & $-0.015 *$ \\
\hline & {$[0.32]$} & {$[0.93]$} & [0.52] & {$[0.55]$} & [1.95] \\
\hline \multirow{2}{*}{ month -6} & -0.006 & $-0.003 * *$ & -0.002 & 0.062 & -0.011 \\
\hline & {$[0.45]$} & [1.99] & [0.47] & {$[0.88]$} & [1.45] \\
\hline \multirow[t]{2}{*}{ month -5} & 0.007 & -0.001 & -0.003 & -0.019 & $-0.020 * *$ \\
\hline & [0.60] & {$[0.88]$} & [0.64] & {$[0.27]$} & [2.54] \\
\hline \multirow[t]{2}{*}{ month -4} & 0.000 & $-0.002 *$ & $0.011^{* *}$ & 0.021 & 0.001 \\
\hline & {$[0.01]$} & {$[1.77]$} & {$[2.27]$} & {$[0.31]$} & {$[0.16]$} \\
\hline \multirow[t]{2}{*}{ month -3} & 0.016 & -0.002 & 0.002 & 0.028 & 0.003 \\
\hline & [1.32] & [1.52] & [0.49] & {$[0.40]$} & [0.33] \\
\hline \multirow[t]{2}{*}{ month -2} & 0.013 & -0.001 & 0.006 & -0.060 & $0.030 * * *$ \\
\hline & [1.05] & {$[0.83]$} & [1.17] & {$[0.84]$} & [3.73] \\
\hline \multirow[t]{2}{*}{ month -1} & 0.001 & $-0.003 *$ & $0.018 * * *$ & $-0.225 * * *$ & $0.057 * * *$ \\
\hline & [0.09] & [1.75] & [3.51] & [2.87] & [7.00] \\
\hline month 0 -elections & 0.004 & $-0.004 * * *$ & 0.002 & -0.105 & $0.055^{* * *}$ \\
\hline & {$[0.31]$} & [2.71] & [0.42] & [1.37] & [6.81] \\
\hline month +1 & -0.015 & 0.000 & -0.005 & 0.091 & $-0.016 *$ \\
\hline & [1.13] & [0.15] & [0.93] & {$[1.22]$} & [1.93] \\
\hline month +2 & 0.008 & -0.001 & -0.004 & $0.136 *$ & -0.011 \\
\hline & [0.55] & {$[0.77]$} & [0.82] & [1.88] & [1.40] \\
\hline month +3 & 0.010 & 0.001 & $-0.011 * *$ & 0.098 & 0.002 \\
\hline & {$[0.72]$} & {$[0.98]$} & [2.19] & [1.40] & [0.19] \\
\hline month +4 & 0.003 & 0.000 & $-0.009 *$ & 0.097 & 0.006 \\
\hline & {$[0.20]$} & [0.15] & [1.71] & [1.40] & [0.75] \\
\hline month +5 & 0.010 & -0.001 & -0.003 & 0.023 & -0.009 \\
\hline & {$[0.72]$} & {$[0.35]$} & [0.53] & [0.34] & [1.12] \\
\hline month +6 & 0.012 & 0.000 & -0.003 & 0.081 & 0.011 \\
\hline & [0.84] & [0.04] & {$[0.60]$} & [1.17] & [1.34] \\
\hline month +7 & 0.008 & -0.001 & -0.008 & 0.012 & -0.008 \\
\hline & {$[0.56]$} & {$[0.46]$} & [1.60] & [0.17] & {$[0.96]$} \\
\hline month +8 & -0.016 & -0.002 & 0.003 & 0.060 & -0.012 \\
\hline & [1.16] & {$[1.56]$} & [0.55] & {$[0.86]$} & [1.45] \\
\hline month +9 & 0.004 & 0.000 & -0.001 & 0.109 & -0.005 \\
\hline & {$[0.31]$} & {$[0.00]$} & {$[0.22]$} & [1.59] & {$[0.61]$} \\
\hline month +10 & -0.003 & 0.000 & 0.000 & 0.031 & -0.006 \\
\hline & {$[0.24]$} & {$[0.24]$} & [0.03] & {$[0.38]$} & {$[0.74]$} \\
\hline month +11 & 0.007 & $0.003 *$ & 0.003 & -0.103 & 0.004 \\
\hline & {$[0.53]$} & [1.84] & {$[0.62]$} & [1.16] & {$[0.48]$} \\
\hline month +12 & -0.013 & -0.001 & 0.001 & -0.080 & $0.052 * * *$ \\
\hline & {$[1.00]$} & {$[0.54]$} & [0.19] & {$[0.90]$} & [6.43] \\
\hline Term in power & -0.001 & $-0.001 * *$ & $0.004^{* * *}$ & -0.009 & -0.004 \\
\hline & {$[0.30]$} & {$[2.08]$} & [3.05] & {$[0.25]$} & [1.64] \\
\hline Left & -0.016 & 0.000 & -0.009 & 0.000 & $-0.021 * *$ \\
\hline & {$[1.22]$} & {$[0.15]$} & [1.58] & [.] & {$[2.40]$} \\
\hline Lag -1 & $-0.411^{* * *}$ & $0.073 * * *$ & $0.464 * * *$ & $0.420 * * *$ & $0.401 * * *$ \\
\hline & [33.96] & [7.69] & [41.29] & [22.37] & [35.67] \\
\hline Lag -2 & $-0.184 * * *$ & $-0.055^{* * *}$ & $0.115^{* * *}$ & $0.200 * * *$ & $0.193 * * *$ \\
\hline & [14.20] & [5.92] & [9.32] & [9.90] & [16.03] \\
\hline Lag -3 & $-0.117 * * *$ & $-0.025 * * *$ & $0.161^{* * * *}$ & $0.148 * * *$ & $0.101 * * *$ \\
\hline & [9.12] & {$[2.70]$} & [12.99] & {$[7.25]$} & [8.39] \\
\hline Lag -4 & $-0.061 * * *$ & 0.011 & $0.055^{* * *}$ & $0.050 * * *$ & $0.071 * * *$ \\
\hline & [5.17] & {$[1.22]$} & {$[4.88]$} & {$[2.60]$} & {$[6.42]$} \\
\hline Constant & 0.008 & 0.001 & $-0.016 * * *$ & -0.089 & $-0.035 * * *$ \\
\hline & [1.04] & [1.57] & [5.09] & [1.39] & {$[7.26]$} \\
\hline Observations & 6944 & 10749 & 7970 & 2767 & 8002 \\
\hline \# of regions & 86 & 86 & 86 & 85 & 86 \\
\hline $\mathbf{R}^{2}$ & 0.148 & 0.013 & 0.487 & 0.493 & 0.447 \\
\hline
\end{tabular}

Note: All dependent variables are in logs and de-trended. All except inflation and prices are measured in real terms per capita. Absolute values of $t$-statistics are in parentheses. $* * *, * *$ and $*$ denote significance at 1,5 and $10 \%$ level, respectively. Regional fixed effects included. 
Table 4. Determinants of the magnitude of the budget cycle, cross-section

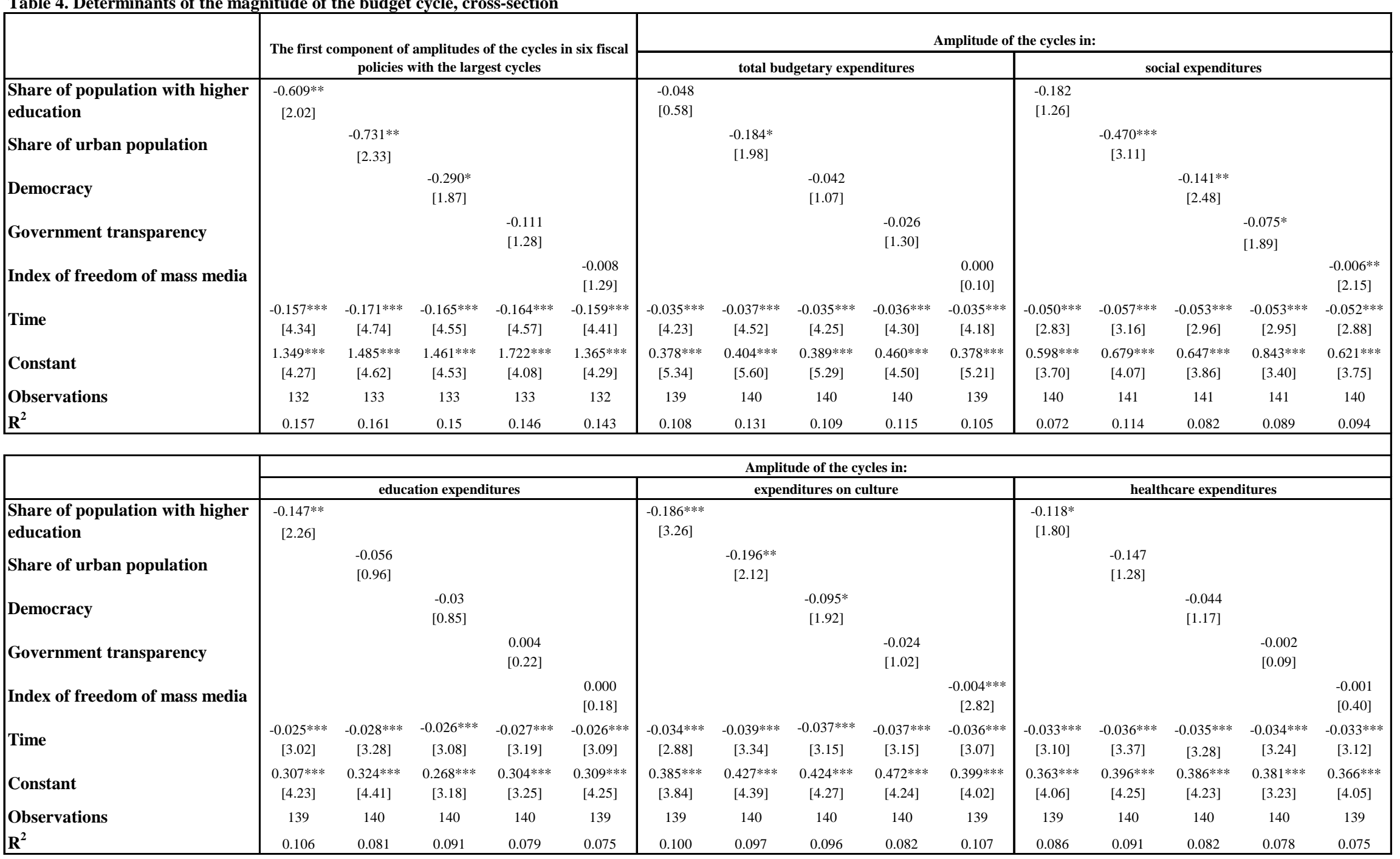

Note: Absolute values of $t$-statistics are in parentheses. $* * *, * *$ and $*$ denote significance at 1,5 and $10 \%$ level, respectively. Standard errors are robust and adjusted for clusters within regions. 


\begin{tabular}{|c|c|c|c|c|c|c|c|c|c|c|c|c|c|c|c|c|c|c|}
\hline & 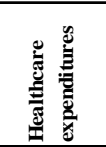 & 竞 & 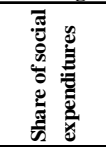 & 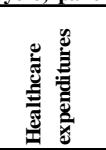 & 氙 & 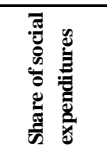 & 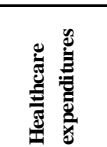 & 竞 & 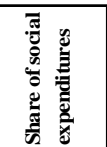 & 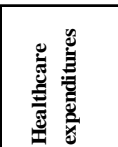 & 童 & 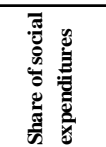 & 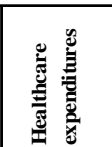 & 总 & 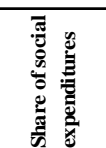 & 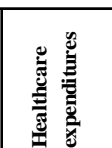 & 䓛 & 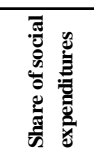 \\
\hline X stands for: & \multicolumn{3}{|c|}{ Share of educated population } & \multicolumn{3}{|c|}{ Share of urban population } & \multicolumn{3}{|c|}{ Democracy } & \multicolumn{3}{|c|}{ Government transparency } & \multicolumn{3}{|c|}{ Freedom of mass media } & \multirow{2}{*}{\multicolumn{3}{|c|}{ Time }} \\
\hline Month -3*X & $0.165^{*}$ & 0.022 & -0.051 & 0.101 & 0.056 & -0.063 & 0.024 & -0.005 & -0.043 & 0.029 & \begin{tabular}{c|c|}
-0.026 \\
\end{tabular} & $\begin{array}{c}-0.027 \\
\end{array}$ & 0.001 & 0.002 & 0.001 & & & \\
\hline & [1.91] & {$[0.16]$} & {$[0.40]$} & [1.15] & {$[0.44]$} & [0.56] & [0.95] & {$[0.13]$} & [1.25] & [1.24] & [0.74] & [0.82] & [0.44] & {$[0.71]$} & {$[0.29]$} & [1.06] & {$[0.72]$} & [1.38] \\
\hline Month $-2 * X$ & $\begin{array}{c}-0.183^{* *} \\
{[2.10]}\end{array}$ & $\begin{array}{c}-0.302^{* *} \\
{[2.29]}\end{array}$ & $\begin{array}{l}-0.067 \\
{[0.54]}\end{array}$ & $\begin{array}{l}-0.080 \\
{[0.86]}\end{array}$ & $\begin{array}{c}-0.156 \\
{[1.17]}\end{array}$ & $\begin{array}{c}-0.172 \\
{[1.46]}\end{array}$ & $\begin{array}{c}-0.024 \\
{[0.95]}\end{array}$ & $\begin{array}{l}-0.037 \\
{[0.99]}\end{array}$ & $\begin{array}{l}-0.032 \\
{[0.94]}\end{array}$ & $\begin{array}{l}-0.032 \\
{[1.39]}\end{array}$ & $\begin{array}{l}-0.048 \\
{[1.37]}\end{array}$ & $\begin{array}{l}-0.014 \\
{[0.46]}\end{array}$ & $\begin{array}{l}-0.003 \\
{[1.63]}\end{array}$ & $\begin{array}{c}-0.005^{* *} \\
{[2.00]}\end{array}$ & $\begin{array}{l}-0.004 \\
{[1.64]}\end{array}$ & $\begin{array}{c}-0.017 * \\
{[1.82]}\end{array}$ & $\begin{array}{l}-0.014 \\
{[0.96]}\end{array}$ & $\begin{array}{l}0.001 \\
{[0.08]}\end{array}$ \\
\hline Month $-1 * X$ & $\begin{array}{l}-0.122 \\
{[1.34]}\end{array}$ & $\begin{array}{c}-0.039 \\
{[0.29]}\end{array}$ & $\begin{array}{l}-0.057 \\
{[0.41]}\end{array}$ & $\begin{array}{l}0.065 \\
{[0.70]}\end{array}$ & $\begin{array}{l}-0.183 \\
{[1.37]}\end{array}$ & $\begin{array}{c}-0.248 * * \\
{[2.07]}\end{array}$ & $\begin{array}{l}0.003 \\
{[0.12]}\end{array}$ & $\begin{array}{c}-0.091 * * \\
{[2.31]}\end{array}$ & $\begin{array}{c}-0.079 * * \\
{[2.16]}\end{array}$ & $\begin{array}{l}-0.010 \\
{[0.40]}\end{array}$ & $\begin{array}{c}-0.106 * * * \\
{[2.89]}\end{array}$ & $\begin{array}{c}-0.054^{*} \\
{[1.65]}\end{array}$ & $\begin{array}{l}0.000 \\
{[0.09]}\end{array}$ & $\begin{array}{c}-0.009 * * * \\
{[3.34]}\end{array}$ & $\begin{array}{c}-0.009 * * * \\
{[3.61]}\end{array}$ & \begin{tabular}{|c}
$-0.038 * * *$ \\
{$[3.45]$}
\end{tabular} & $\begin{array}{c}-0.059 * * * \\
{[3.64]}\end{array}$ & $\begin{array}{c}-0.031^{* *} \\
{[2.04]}\end{array}$ \\
\hline Month $0 * X$ & $\begin{array}{l}-0.034 \\
{[0.38]}\end{array}$ & $\begin{array}{l}-0.135 \\
{[0.99]}\end{array}$ & $\begin{array}{l}-0.204 \\
{[1.49]}\end{array}$ & $\begin{array}{l}0.047 \\
{[0.52]}\end{array}$ & $\begin{array}{l}0.000 \\
{[0.00]}\end{array}$ & $\begin{array}{c}-0.269 * * \\
{[2.23]}\end{array}$ & $\begin{array}{c}-0.055^{* *} \\
{[2.01]}\end{array}$ & $\begin{array}{l}-0.023 \\
{[0.59]}\end{array}$ & $\begin{array}{l}-0.016 \\
{[0.43]}\end{array}$ & $\begin{array}{l}-0.009 \\
{[0.39]}\end{array}$ & $\begin{array}{l}0.029 \\
{[0.79]}\end{array}$ & $\begin{array}{l}0.033 \\
{[1.00]}\end{array}$ & \begin{tabular}{|c}
$-0.005^{* * * *}$ \\
{$[2.94]$}
\end{tabular} & $\begin{array}{l}-0.003 \\
{[1.14]}\end{array}$ & $\begin{array}{l}-0.001 \\
{[0.58]}\end{array}$ & $\begin{array}{l}-0.017 \\
{[1.51]}\end{array}$ & $\begin{array}{l}-0.007 \\
{[0.43]}\end{array}$ & $\begin{array}{l}0.025 * \\
{[1.68]}\end{array}$ \\
\hline Month -3 & $\begin{array}{l}0.013 \\
{[0.62]}\end{array}$ & $\begin{array}{l}0.029 \\
{[0.91]}\end{array}$ & $\begin{array}{l}-0.025 \\
{[0.85]}\end{array}$ & $\begin{array}{l}0.012 \\
{[0.53]}\end{array}$ & $\begin{array}{l}0.038 \\
{[1.16]}\end{array}$ & $\begin{array}{l}-0.013 \\
{[0.44]}\end{array}$ & $\begin{array}{l}-0.057 \\
{[0.74]}\end{array}$ & $\begin{array}{l}0.044 \\
{[0.37]}\end{array}$ & $\begin{array}{l}0.107 \\
{[0.98]}\end{array}$ & $\begin{array}{l}0.012 \\
{[0.56]}\end{array}$ & $\begin{array}{l}0.031 \\
{[0.95]}\end{array}$ & $\begin{array}{l}-0.021 \\
{[0.71]}\end{array}$ & $\begin{array}{l}0.019 \\
{[0.88]}\end{array}$ & $\begin{array}{l}0.033 \\
{[1.00]}\end{array}$ & $\begin{array}{c}-0.022 \\
{[0.73]}\end{array}$ & $\begin{array}{l}0.006 \\
{[0.29]}\end{array}$ & $\begin{array}{l}0.035 \\
{[1.07]}\end{array}$ & $\begin{array}{c}-0.021 \\
{[0.67]}\end{array}$ \\
\hline Month -2 & $\begin{array}{c}0.045^{* *} \\
{[2.15]}\end{array}$ & $\begin{array}{c}0.079 * * \\
{[2.49]}\end{array}$ & $\begin{array}{l}0.050^{*} \\
{[1.70]}\end{array}$ & $\begin{array}{c}0.051^{* *} \\
{[2.32]}\end{array}$ & $\begin{array}{c}0.095 * * * * \\
{[2.89]}\end{array}$ & $\begin{array}{c}0.076 * * \\
{[2.51]}\end{array}$ & & $\begin{array}{l}0.193^{*} \\
{[1.65]}\end{array}$ & & $\begin{array}{c}0.047 * * \\
{[2.22]}\end{array}$ & $\begin{array}{c}0.084 * * * \\
{[2.62]}\end{array}$ & $\begin{array}{l}0.057^{*} \\
{[1.92]}\end{array}$ & $\begin{array}{c}0.053^{* *} \\
{[2.46]}\end{array}$ & $\begin{array}{c}0.089 * * * \\
{[2.75]}\end{array}$ & $\begin{array}{c}0.060^{* * *} \\
{[2.01]}\end{array}$ & $\begin{array}{l}0.039^{*} \\
{[1.77]}\end{array}$ & $\begin{array}{c}0.086^{* * *} \\
{[2.61]}\end{array}$ & $\begin{array}{c}0.070^{* *} \\
{[2.29]}\end{array}$ \\
\hline Month -1 & $\begin{array}{c}0.109 * * * * \\
{[5.01]}\end{array}$ & $\begin{array}{c}0.260^{* * * *} \\
{[7.86]}\end{array}$ & $\begin{array}{c}0.141 * * * \\
{[4.60]}\end{array}$ & $\begin{array}{c}0.106 * * * \\
{[4.58]}\end{array}$ & $\begin{array}{c}0.259 * * * \\
{[7.58]}\end{array}$ & $\begin{array}{c}0.131 * * * \\
{[4.20]}\end{array}$ & $\begin{array}{l}0.097 \\
{[1.18]}\end{array}$ & $\begin{array}{c}0.524 * * * \\
{[4.31]}\end{array}$ & $\begin{array}{c}0.369 * * * \\
{[3.25]}\end{array}$ & \begin{tabular}{|c}
$0.107 * * *$ \\
{$[4.81]$}
\end{tabular} & $\begin{array}{c}0.252 * * * \\
{[7.55]}\end{array}$ & $\begin{array}{c}0.131 * * * \\
{[4.28]}\end{array}$ & \begin{tabular}{|c}
$0.113 * * * *$ \\
{$[5.05]$}
\end{tabular} & $\begin{array}{c}0.263 * * * \\
{[7.87]}\end{array}$ & $\begin{array}{c}0.142 * * * \\
{[4.63]}\end{array}$ & \begin{tabular}{|c}
$0.082 * * * *$ \\
{$[3.48]$}
\end{tabular} & $\begin{array}{c}0.223 * * * \\
{[6.40]}\end{array}$ & $\begin{array}{c}0.112 * * * \\
{[3.52]}\end{array}$ \\
\hline Month 0 & $\begin{array}{c}-0.064^{* * * *} \\
{[2.97]}\end{array}$ & $\begin{array}{l}0.014 \\
{[0.42]}\end{array}$ & $\begin{array}{c}0.064^{* *} \\
{[2.14]}\end{array}$ & $\begin{array}{c}-0.069^{* * * *} \\
{[3.02]}\end{array}$ & $\begin{array}{l}0.022 \\
{[0.64]}\end{array}$ & $\begin{array}{c}0.091 * * * \\
{[2.98]}\end{array}$ & $\begin{array}{l}0.104 \\
{[1.23]}\end{array}$ & $\begin{array}{l}0.086 \\
{[0.71]}\end{array}$ & $\begin{array}{l}0.113 \\
{[1.00]}\end{array}$ & \begin{tabular}{|c}
$-0.060^{* * * *}$ \\
{$[2.74]$}
\end{tabular} & $\begin{array}{l}0.017 \\
{[0.51]}\end{array}$ & $\begin{array}{c}0.067 * * \\
{[2.26]}\end{array}$ & \begin{tabular}{|c}
$-0.058 * * *$ \\
{$[2.60]$}
\end{tabular} & $\begin{array}{l}0.019 \\
{[0.58]}\end{array}$ & $\begin{array}{c}0.068^{* *} \\
{[2.29]}\end{array}$ & \begin{tabular}{|c}
$-0.061 * * *$ \\
{$[2.60]$}
\end{tabular} & $\begin{array}{l}0.026 \\
{[0.77]}\end{array}$ & $\begin{array}{c}0.096 * * * \\
{[3.09]}\end{array}$ \\
\hline Month +1 & $\begin{array}{c}-0.048^{* *} \\
{[2.23]}\end{array}$ & $\begin{array}{c}-0.090^{* * * *} \\
{[2.76]}\end{array}$ & $\begin{array}{l}-0.047 \\
{[1.62]}\end{array}$ & $\begin{array}{c}-0.043^{*} \\
{[1.91]}\end{array}$ & $\begin{array}{c}-0.087 * * * \\
{[2.61]}\end{array}$ & $\begin{array}{l}-0.035 \\
{[1.18]}\end{array}$ & $\begin{array}{c}-0.039^{*} \\
{[1.78]}\end{array}$ & $\begin{array}{c}-0.096 * * * \\
{[2.93]}\end{array}$ & $\begin{array}{l}-0.047 \\
{[1.59]}\end{array}$ & $\begin{array}{c}-0.039 * \\
{[1.79]}\end{array}$ & $\begin{array}{c}-0.096 * * * * \\
{[2.94]}\end{array}$ & $\begin{array}{l}-0.047 \\
{[1.60]}\end{array}$ & $\begin{array}{c}-0.039 * \\
{[1.79]}\end{array}$ & $\begin{array}{c}-0.097 * * * \\
{[2.96]}\end{array}$ & $\begin{array}{l}-0.047 \\
{[1.59]}\end{array}$ & $\begin{array}{l}-0.030 \\
{[1.32]}\end{array}$ & $\begin{array}{c}-0.079 * * \\
{[2.37]}\end{array}$ & $\begin{array}{l}-0.034 \\
{[1.13]}\end{array}$ \\
\hline Month +2 & \begin{tabular}{|c}
$-0.047 * *$ \\
{$[2.19]$}
\end{tabular} & $\begin{array}{l}-0.044 \\
{[1.33]}\end{array}$ & $\begin{array}{l}-0.020 \\
{[0.66]}\end{array}$ & $\begin{array}{l}-0.032 \\
{[1.46]}\end{array}$ & $\begin{array}{l}-0.033 \\
{[0.99]}\end{array}$ & $\begin{array}{l}-0.006 \\
{[0.19]}\end{array}$ & $\begin{array}{c}-0.042^{*} \\
{[1.95]}\end{array}$ & $\begin{array}{l}-0.042 \\
{[1.28]}\end{array}$ & $\begin{array}{l}-0.017 \\
{[0.57]}\end{array}$ & $\begin{array}{c}-0.042^{*} \\
{[1.95]}\end{array}$ & $\begin{array}{l}-0.042 \\
{[1.29]}\end{array}$ & $\begin{array}{l}-0.017 \\
{[0.57]}\end{array}$ & $\begin{array}{c}-0.042^{*} \\
{[1.93]}\end{array}$ & $\begin{array}{l}-0.048 \\
{[1.46]}\end{array}$ & $\begin{array}{l}-0.021 \\
{[0.71]}\end{array}$ & $\begin{array}{l}-0.020 \\
{[0.89]}\end{array}$ & $\begin{array}{l}-0.026 \\
{[0.78]}\end{array}$ & $\begin{array}{l}-0.004 \\
{[0.14]}\end{array}$ \\
\hline Month +3 & $\begin{array}{l}0.003 \\
{[0.12]}\end{array}$ & $\begin{array}{l}0.006 \\
{[0.19]}\end{array}$ & $\begin{array}{l}-0.014 \\
{[0.48]}\end{array}$ & $\begin{array}{l}0.011 \\
{[0.48]}\end{array}$ & $\begin{array}{l}0.036 \\
{[1.09]}\end{array}$ & $\begin{array}{l}0.012 \\
{[0.40]}\end{array}$ & $\begin{array}{l}0.011 \\
{[0.50]}\end{array}$ & $\begin{array}{l}0.020 \\
{[0.61]}\end{array}$ & $\begin{array}{l}-0.003 \\
{[0.10]}\end{array}$ & $\begin{array}{l}0.011 \\
{[0.50]}\end{array}$ & $\begin{array}{l}0.020 \\
{[0.61]}\end{array}$ & $\begin{array}{l}-0.003 \\
{[0.10]}\end{array}$ & $\begin{array}{l}0.011 \\
{[0.52]}\end{array}$ & $\begin{array}{l}0.014 \\
{[0.42]}\end{array}$ & $\begin{array}{l}-0.007 \\
{[0.26]}\end{array}$ & $\begin{array}{l}0.022 \\
{[0.99]}\end{array}$ & $\begin{array}{l}0.042 \\
{[1.277}\end{array}$ & $\begin{array}{l}0.013 \\
{[0.43]}\end{array}$ \\
\hline Left & $\begin{array}{l}0.015 \\
{[0.48]}\end{array}$ & $\begin{array}{l}-0.030 \\
{[0.66]}\end{array}$ & $\begin{array}{l}-0.029 \\
{[0.58]}\end{array}$ & & $\begin{array}{l}-0.029 \\
{[0.59]}\end{array}$ & $\begin{array}{l}-0.017 \\
{[0.34]}\end{array}$ & & $\begin{array}{l}-0.029 \\
{[0.62]}\end{array}$ & $\begin{array}{l}-0.027 \\
{[0.55]}\end{array}$ & $\begin{array}{l}0.013 \\
{[0.42]}\end{array}$ & $\begin{array}{l}-0.8 \\
{[0 .}\end{array}$ & $\begin{array}{l}-0.030 \\
{[0.61]}\end{array}$ & $\begin{array}{l}0.014 \\
{[0.45]}\end{array}$ & $\begin{array}{l}-0.028 \\
{[0.60]}\end{array}$ & $\begin{array}{l}-0.026 \\
{[0.53]}\end{array}$ & $\begin{array}{c}0.015 \\
{[0.46]}\end{array}$ & $\begin{array}{l}-0.028 \\
{[0.57]}\end{array}$ & $\begin{array}{l}-0.028 \\
{[0.55]}\end{array}$ \\
\hline Term in power & $\begin{array}{c}0.027 * * * \\
{[3.94]}\end{array}$ & $\begin{array}{c}0.024^{* *} \\
{[2.32]}\end{array}$ & $\begin{array}{l}0.019^{*} \\
{[1.93]}\end{array}$ & $\begin{array}{c}0.031^{* * *} \\
{[4.42]}\end{array}$ & $\begin{array}{c}0.021^{* *} \\
{[2.00]}\end{array}$ & $\begin{array}{l}0.008 \\
{[0.80]}\end{array}$ & $\begin{array}{c}0.027 * * * \\
{[3.89]}\end{array}$ & $\begin{array}{c}0.022 * * \\
{[2.14]}\end{array}$ & $\begin{array}{l}0.017^{*} \\
{[1.73]}\end{array}$ & \begin{tabular}{|c}
$0.027 * * *$ \\
{$[3.93]$}
\end{tabular} & $\begin{array}{c}0.023 * * \\
{[2.20]}\end{array}$ & $\begin{array}{l}0.018^{*} \\
{[1.77]}\end{array}$ & \begin{tabular}{|c}
$0.028 * * *$ \\
{$[4.06]$}
\end{tabular} & $\begin{array}{c}0.022 * * \\
{[2.14]}\end{array}$ & $\begin{array}{l}0.015 \\
{[1.55]}\end{array}$ & $\begin{array}{l}0.000 \\
{[0.01]}\end{array}$ & $\begin{array}{l}0.005 \\
{[0.34]}\end{array}$ & $\begin{array}{l}0.004 \\
{[0.28]}\end{array}$ \\
\hline $\operatorname{lag} 1$ & $\begin{array}{c}0.172 * * * \\
{[13.60]}\end{array}$ & $\begin{array}{c}0.216 * * * \\
{[17.22]}\end{array}$ & $\begin{array}{c}0.210^{* * * *} \\
{[16.07]}\end{array}$ & $\begin{array}{c}0.183^{* * *} \\
{[15.11]}\end{array}$ & $\begin{array}{c}0.198 * * * \\
{[16.49]}\end{array}$ & $\begin{array}{c}0.202 * * * \\
{[16.10]}\end{array}$ & $\begin{array}{c}0.180^{* * *} \\
{[14.45]}\end{array}$ & $\begin{array}{c}0.205 * * * \\
{[16.55]}\end{array}$ & $\begin{array}{c}0.210^{* * * *} \\
{[16.21]}\end{array}$ & \begin{tabular}{|c}
$0.179 * * *$ \\
{$[14.39]$}
\end{tabular} & $\begin{array}{c}0.205^{* * * *} \\
{[16.56]}\end{array}$ & $\begin{array}{c}0.211 * * * \\
{[16.27]}\end{array}$ & \begin{tabular}{|c|}
$0.180^{* * * *}$ \\
{$[14.60]$}
\end{tabular} & $\begin{array}{c}0.206 * * * \\
{[16.76]}\end{array}$ & $\begin{array}{c}0.206 * * * \\
{[16.07]}\end{array}$ & \begin{tabular}{|c|}
$0.178 * * * *$ \\
{$[14.70]$}
\end{tabular} & $\begin{array}{c}0.198 * * * \\
{[16.47]}\end{array}$ & $\begin{array}{c}0.205 * * * \\
{[16.27]}\end{array}$ \\
\hline lag2 & $\begin{array}{c}0.103 * * * \\
{[8.03]}\end{array}$ & $\begin{array}{c}0.189 * * * \\
{[14.74]}\end{array}$ & $\begin{array}{c}0.157 * * * \\
{[11.84]}\end{array}$ & $\begin{array}{c}0.104^{* * *} \\
{[8.50]}\end{array}$ & $\begin{array}{c}0.190 * * * \\
{[15.55]}\end{array}$ & $\begin{array}{c}0.152 * * * \\
{[11.92]}\end{array}$ & $\begin{array}{c}0.096 * * * \\
{[7.62]}\end{array}$ & $\begin{array}{c}0.193^{* * * *} \\
{[15.26]}\end{array}$ & $\begin{array}{c}0.156^{* * *} \\
{[11.88]}\end{array}$ & \begin{tabular}{|c}
$0.096 * * *$ \\
{$[7.64]$}
\end{tabular} & $\begin{array}{c}0.193 * * * \\
{[15.29]}\end{array}$ & $\begin{array}{c}0.157 * * * \\
{[11.91]}\end{array}$ & \begin{tabular}{|c|}
$0.096 * * *$ \\
{$[7.72]$}
\end{tabular} & $\begin{array}{c}0.189 * * * \\
{[15.09]}\end{array}$ & $\begin{array}{c}0.154^{* * * *} \\
{[11.80]}\end{array}$ & \begin{tabular}{|c|}
$0.101 * * *$ \\
{$[8.31]$}
\end{tabular} & $\begin{array}{c}0.189 * * * \\
{[15.49]}\end{array}$ & $\begin{array}{c}0.152 * * * \\
{[11.88]}\end{array}$ \\
\hline lag3 & $\begin{array}{c}0.140 * * * \\
{[11.02]}\end{array}$ & $\begin{array}{c}0.109 * * * \\
{[8.47]}\end{array}$ & $\begin{array}{c}0.122 * * * \\
{[9.27]}\end{array}$ & $\begin{array}{c}0.125 * * * \\
{[10.26]}\end{array}$ & $\begin{array}{c}0.112 * * * \\
{[9.21]}\end{array}$ & $\begin{array}{c}0.132 * * * \\
{[10.39]}\end{array}$ & $\begin{array}{c}0.143 * * * \\
{[11.41]}\end{array}$ & $\begin{array}{c}0.111 * * * \\
{[8.78]}\end{array}$ & $\begin{array}{c}0.118^{* * *} \\
{[9.04]}\end{array}$ & \begin{tabular}{|c|}
$0.143 * * *$ \\
{$[11.43]$}
\end{tabular} & $\begin{array}{c}0.112 * * * \\
{[8.85]}\end{array}$ & $\begin{array}{c}0.118^{* * *} \\
{[9.05]}\end{array}$ & \begin{tabular}{|c|}
$0.137 * * *$ \\
[11.09]
\end{tabular} & $\begin{array}{c}0.117 * * * \\
{[9.33]}\end{array}$ & $\begin{array}{c}0.128 * * * \\
{[9.92]}\end{array}$ & \begin{tabular}{|c|}
$0.122 * * *$ \\
{$[10.03]$}
\end{tabular} & $\begin{array}{c}0.112 * * * \\
{[9.24]}\end{array}$ & $\begin{array}{c}0.132^{* * * *} \\
{[10.37]}\end{array}$ \\
\hline $\operatorname{lag} 4$ & $\begin{array}{c}0.098 * * * \\
{[7.82]}\end{array}$ & $\begin{array}{c}0.098 * * * \\
{[7.87]}\end{array}$ & $\begin{array}{c}0.077 * * * \\
{[5.93]}\end{array}$ & $\begin{array}{c}0.092 * * * \\
{[7.81]}\end{array}$ & $\begin{array}{c}0.097 * * * \\
{[8.30]}\end{array}$ & $\begin{array}{c}0.089 * * * \\
{[7.14]}\end{array}$ & $\begin{array}{c}0.086^{* * * *} \\
{[7.06]}\end{array}$ & $\begin{array}{c}0.094^{* * * *} \\
{[7.79]}\end{array}$ & $\begin{array}{c}0.079 * * * \\
{[6.19]}\end{array}$ & \begin{tabular}{|c}
$0.085 * * *$ \\
{$[7.05]$}
\end{tabular} & $\begin{array}{c}0.094 * * * \\
{[7.76]}\end{array}$ & $\begin{array}{c}0.078^{* * *} \\
{[6.13]}\end{array}$ & \begin{tabular}{|c|}
$0.094 * * *$ \\
{$[7.87]$}
\end{tabular} & $\begin{array}{c}0.097 * * * \\
{[8.10]}\end{array}$ & $\begin{array}{c}0.079 * * * \\
{[6.24]}\end{array}$ & \begin{tabular}{|c}
$0.089 * * *$ \\
{$[7.62]$} \\
$0.012 * * *$ \\
{$[5.39]$}
\end{tabular} & $\begin{array}{c}0.098^{* * *} \\
{[8.34]} \\
0.008^{* *} \\
{[2.33]}\end{array}$ & $\begin{array}{c}0.090^{* * *} \\
{[7.19]} \\
0.001 \\
{[0.38]}\end{array}$ \\
\hline Constant & $\begin{array}{c}-0.091 * * * \\
{[5.74]}\end{array}$ & $\begin{array}{c}-0.101^{* * * *} \\
{[4.16]}\end{array}$ & $\begin{array}{c}-0.059 * * \\
{[2.34]}\end{array}$ & $\begin{array}{c}-0.053 * * * \\
{[3.26]}\end{array}$ & $\begin{array}{c}-0.069 * * * \\
{[2.81]}\end{array}$ & $\begin{array}{c}-0.058^{* *} \\
{[2.24]}\end{array}$ & $\begin{array}{c}-0.066^{* * * *} \\
{[4.16]}\end{array}$ & $\begin{array}{c}-0.086 * * * \\
{[3.59]}\end{array}$ & $\begin{array}{c}-0.062^{* *} \\
{[2.46]}\end{array}$ & \begin{tabular}{|c}
$-0.066 * * *$ \\
{$[4.16]$}
\end{tabular} & $\begin{array}{c}-0.086^{* * * *} \\
{[3.60]}\end{array}$ & $\begin{array}{c}-0.061 * * \\
{[2.42]}\end{array}$ & \begin{tabular}{|c}
$-0.066 * * * *$ \\
{$[4.20]$}
\end{tabular} & $\begin{array}{c}-0.082 * * * \\
{[3.46]}\end{array}$ & $\begin{array}{c}-0.058^{* *} \\
{[2.31]}\end{array}$ & $\begin{array}{l}-0.015 \\
{[0.84]}\end{array}$ & $\begin{array}{c}-0.049^{*} \\
{[1.77]}\end{array}$ & $\begin{array}{c}-0.048^{*} \\
{[1.68]}\end{array}$ \\
\hline $\begin{array}{l}\text { Observation } \\
\text { Number of }\end{array}$ & $\begin{array}{c}6389 \\
76\end{array}$ & $\begin{array}{c}6410 \\
76\end{array}$ & $\begin{array}{c}5946 \\
76\end{array}$ & $\begin{array}{c}6966 \\
86\end{array}$ & $\begin{array}{c}7004 \\
86\end{array}$ & $\begin{array}{c}6388 \\
86\end{array}$ & $\begin{array}{c}6600 \\
80\end{array}$ & $\begin{array}{c}6593 \\
80\end{array}$ & $\begin{array}{c}6063 \\
80\end{array}$ & $\begin{array}{c}6600 \\
80\end{array}$ & $\begin{array}{c}6593 \\
80\end{array}$ & $\begin{array}{c}6063 \\
80\end{array}$ & $\begin{array}{c}6682 \\
81\end{array}$ & $\begin{array}{c}6671 \\
81\end{array}$ & $\begin{array}{c}6159 \\
81\end{array}$ & $\begin{array}{c}6966 \\
86\end{array}$ & $\begin{array}{c}7004 \\
86\end{array}$ & $\begin{array}{c}6388 \\
86\end{array}$ \\
\hline R-squared & 0.125 & 0.218 & 0.166 & 0.121 & 0.202 & 0.168 & 0.121 & 0.209 & 0.163 & 0.121 & 0.209 & 0.162 & 0.124 & 0.215 & 0.165 & 0.125 & 0.203 & 0.168 \\
\hline
\end{tabular}

Note: All dependent variables are de-trended and in logs. The are measured in real terms per capita. Absolute values of t-statistics are in parentheses. ***,**, and * denote significance at 1,5, and $10 \%$ level, respectively. Regional fixed effects included. 


\begin{tabular}{|c|c|c|c|c|c|c|c|c|c|c|}
\hline Dependent Variable: & 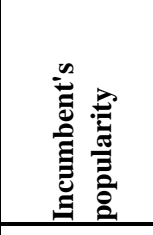 & 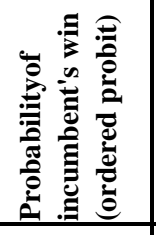 & 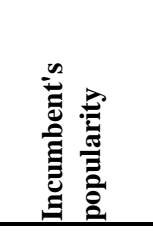 & 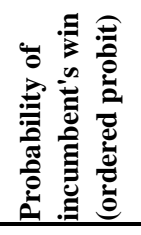 & 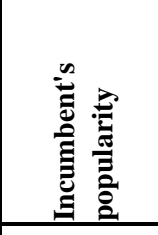 & 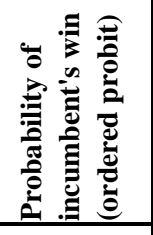 & 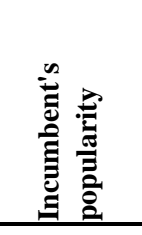 & 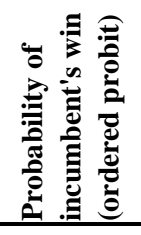 & 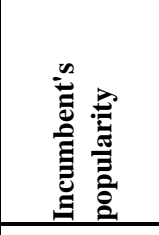 & 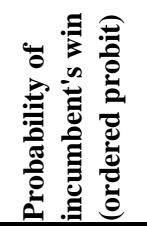 \\
\hline X stands for: & \multicolumn{2}{|c|}{$\begin{array}{l}\text { Share of population with } \\
\text { higher education }\end{array}$} & \multicolumn{2}{|c|}{$\begin{array}{l}\text { Share of urban } \\
\text { population }\end{array}$} & \multicolumn{2}{|c|}{$\begin{array}{c}\text { Index of freedom of mass } \\
\text { media }\end{array}$} & \multicolumn{2}{|c|}{ Democracy } & \multicolumn{2}{|c|}{ Govenment transparency } \\
\hline Amplitude & $\begin{array}{c}0.338^{* *} \\
{[2.36]}\end{array}$ & $\begin{array}{l}0.291^{*} \\
{[1.89]}\end{array}$ & $\begin{array}{c}0.353 * * \\
{[2.46]}\end{array}$ & $\begin{array}{l}0.289^{*} \\
{[1.84]}\end{array}$ & $\begin{array}{c}0.310^{* *} \\
{[2.34]}\end{array}$ & $\begin{array}{l}0.268^{*} \\
{[1.72]}\end{array}$ & $\begin{array}{c}0.311^{* *} \\
{[2.36]}\end{array}$ & $\begin{array}{l}0.241^{*} \\
{[1.65]}\end{array}$ & $\begin{array}{c}0.340 * * \\
{[2.43]}\end{array}$ & $\begin{array}{l}0.251^{*} \\
{[1.76]}\end{array}$ \\
\hline Amplitude*X & $\begin{array}{l}-0.458 \\
{[0.89]}\end{array}$ & $\begin{array}{l}0.296 \\
{[0.52]}\end{array}$ & $\begin{array}{l}-0.249 \\
{[0.32]}\end{array}$ & $\begin{array}{c}0.367 \\
{[0.43]}\end{array}$ & $\begin{array}{c}-0.016^{* *} \\
{[2.36]}\end{array}$ & $\begin{array}{l}-0.003 \\
{[0.36]}\end{array}$ & $\begin{array}{c}-0.455^{*} \\
{[1.70]}\end{array}$ & $\begin{array}{l}-0.357 \\
{[0.91]}\end{array}$ & $\begin{array}{l}0.007 \\
{[0.05]}\end{array}$ & $\begin{array}{l}-0.188 \\
{[0.99]}\end{array}$ \\
\hline Amplitude*Time & $\begin{array}{c}0.074 \\
{[1.05]}\end{array}$ & $\begin{array}{c}0.061 \\
{[1.04]}\end{array}$ & $\begin{array}{l}0.065 \\
{[0.98]}\end{array}$ & $\begin{array}{c}0.069 \\
{[1.11]}\end{array}$ & $\begin{array}{l}0.056 \\
{[0.96]}\end{array}$ & $\begin{array}{c}0.049 \\
{[0.90]}\end{array}$ & $\begin{array}{c}0.073 \\
{[1.04]}\end{array}$ & $\begin{array}{l}0.068 \\
{[1.15]}\end{array}$ & $\begin{array}{l}0.073 \\
{[1.02]}\end{array}$ & $\begin{array}{l}0.076 \\
{[1.25]}\end{array}$ \\
\hline $\mathbf{X}$ & $\begin{array}{c}0.672 \\
{[1.37]}\end{array}$ & $\begin{array}{c}0.207 \\
{[0.38]}\end{array}$ & $\begin{array}{c}1.107 * * \\
{[2.11]}\end{array}$ & $\begin{array}{c}0.733 \\
{[1.37]}\end{array}$ & $\begin{array}{c}0.023^{* * * *} \\
{[3.21]}\end{array}$ & $\begin{array}{l}0.016^{*} \\
{[1.71]}\end{array}$ & $\begin{array}{l}-0.133 \\
{[0.59]}\end{array}$ & $\begin{array}{l}-0.077 \\
{[0.29]}\end{array}$ & $\begin{array}{l}-0.057 \\
{[0.45]}\end{array}$ & $\begin{array}{l}-0.036 \\
{[0.29]}\end{array}$ \\
\hline Time & $\begin{array}{c}0.170^{* * *} \\
{[3.12]}\end{array}$ & $\begin{array}{c}0.188^{* * *} \\
{[2.74]}\end{array}$ & $\begin{array}{c}0.183^{* * * *} \\
{[3.23]}\end{array}$ & $\begin{array}{c}0.202^{* * *} \\
{[2.98]}\end{array}$ & $\begin{array}{c}0.175^{* * * *} \\
{[3.34]}\end{array}$ & $\begin{array}{c}0.199 * * * \\
{[3.03]}\end{array}$ & $\begin{array}{c}0.157 * * * \\
{[2.75]}\end{array}$ & $\begin{array}{c}0.186 * * * \\
{[2.77]}\end{array}$ & $\begin{array}{c}0.152^{* *} \\
{[2.61]}\end{array}$ & $\begin{array}{c}0.187 * * * \\
{[2.82]}\end{array}$ \\
\hline Left & $\begin{array}{c}-0.842^{* * *} \\
{[3.77]}\end{array}$ & $\begin{array}{c}-0.892 * * * \\
{[4.25]}\end{array}$ & $\begin{array}{c}-0.814^{* * *} \\
{[3.70]}\end{array}$ & $\begin{array}{c}-0.828 * * * \\
{[4.00]}\end{array}$ & $\begin{array}{c}-0.821^{* * *} \\
{[4.06]}\end{array}$ & $\begin{array}{c}-0.836^{* * *} \\
{[4.02]}\end{array}$ & $\begin{array}{c}-0.918^{* * *} \\
{[4.20]}\end{array}$ & $\begin{array}{c}-0.895^{* * *} \\
{[4.14]}\end{array}$ & $\begin{array}{c}-0.937 * * * \\
{[4.13]}\end{array}$ & $\begin{array}{c}-0.902 * * * \\
{[4.16]}\end{array}$ \\
\hline $\begin{array}{l}\text { Relative Share of } \\
\text { Soc. Exp. }\end{array}$ & $\begin{array}{l}0.009 \\
{[0.02]}\end{array}$ & $\begin{array}{c}0.158 \\
{[0.33]}\end{array}$ & $\begin{array}{c}0.08 \\
{[0.16]}\end{array}$ & $\begin{array}{c}0.144 \\
{[0.30]}\end{array}$ & $\begin{array}{l}0.006 \\
{[0.01]}\end{array}$ & $\begin{array}{c}0.119 \\
{[0.24]}\end{array}$ & $\begin{array}{l}-0.171 \\
{[0.33]}\end{array}$ & $\begin{array}{l}-0.02 \\
{[0.04]}\end{array}$ & $\begin{array}{c}-0.1 \\
{[0.17]}\end{array}$ & $\begin{array}{l}-0.074 \\
{[0.16]}\end{array}$ \\
\hline Relative Product & $\begin{array}{l}1.595 \\
{[1.31]}\end{array}$ & $\begin{array}{l}1.095 \\
{[0.96]}\end{array}$ & $\begin{array}{l}1.456 \\
{[1.24]}\end{array}$ & $\begin{array}{l}1.049 \\
{[0.99]}\end{array}$ & $\begin{array}{l}1.653 \\
{[1.43]}\end{array}$ & $\begin{array}{l}1.029 \\
{[0.96]}\end{array}$ & $\begin{array}{l}1.277 \\
{[1.05]}\end{array}$ & $\begin{array}{c}0.89 \\
{[0.83]}\end{array}$ & $\begin{array}{c}1.2 \\
{[0.97]}\end{array}$ & $\begin{array}{c}0.894 \\
{[0.84]}\end{array}$ \\
\hline Relative Price & $\begin{array}{c}0.758 \\
{[0.22]}\end{array}$ & $\begin{array}{l}1.657 \\
{[0.47]}\end{array}$ & $\begin{array}{c}0.184 \\
{[0.05]}\end{array}$ & $\begin{array}{l}1.591 \\
{[0.49]}\end{array}$ & $\begin{array}{l}0.408 \\
{[0.13]}\end{array}$ & $\begin{array}{l}1.635 \\
{[0.51]}\end{array}$ & $\begin{array}{l}-0.801 \\
{[0.21]}\end{array}$ & $\begin{array}{l}1.065 \\
{[0.32]}\end{array}$ & $\begin{array}{l}-0.76 \\
{[0.19]}\end{array}$ & $\begin{array}{c}0.517 \\
{[0.15]}\end{array}$ \\
\hline Constant & $\begin{array}{c}0.841^{* * * *} \\
{[5.03]}\end{array}$ & & $\begin{array}{c}0.826^{* * *} \\
{[4.66]}\end{array}$ & & $\begin{array}{c}0.831^{* * *} \\
{[4.98]}\end{array}$ & & $\begin{array}{c}0.879 * * * \\
{[4.94]}\end{array}$ & & $\begin{array}{c}0.888 * * * \\
{[4.87]}\end{array}$ & \\
\hline Observations & 120 & 120 & 120 & 120 & 120 & 120 & 120 & 120 & 120 & 120 \\
\hline $\mathbf{R}^{2}$ & 0.245 & & 0.252 & & 0.294 & & 0.241 & & 0.232 & \\
\hline
\end{tabular}

Note: Absolute values of $t$-statistics are in parentheses. ***, ** and * denote significance at 1,5 and $10 \%$ level, respectively. Standard errors are robust and adjusted for clusters within regions. 
Figure 1. Elections and actual series of regional per capital social expenditures (smoothed by a moving average)
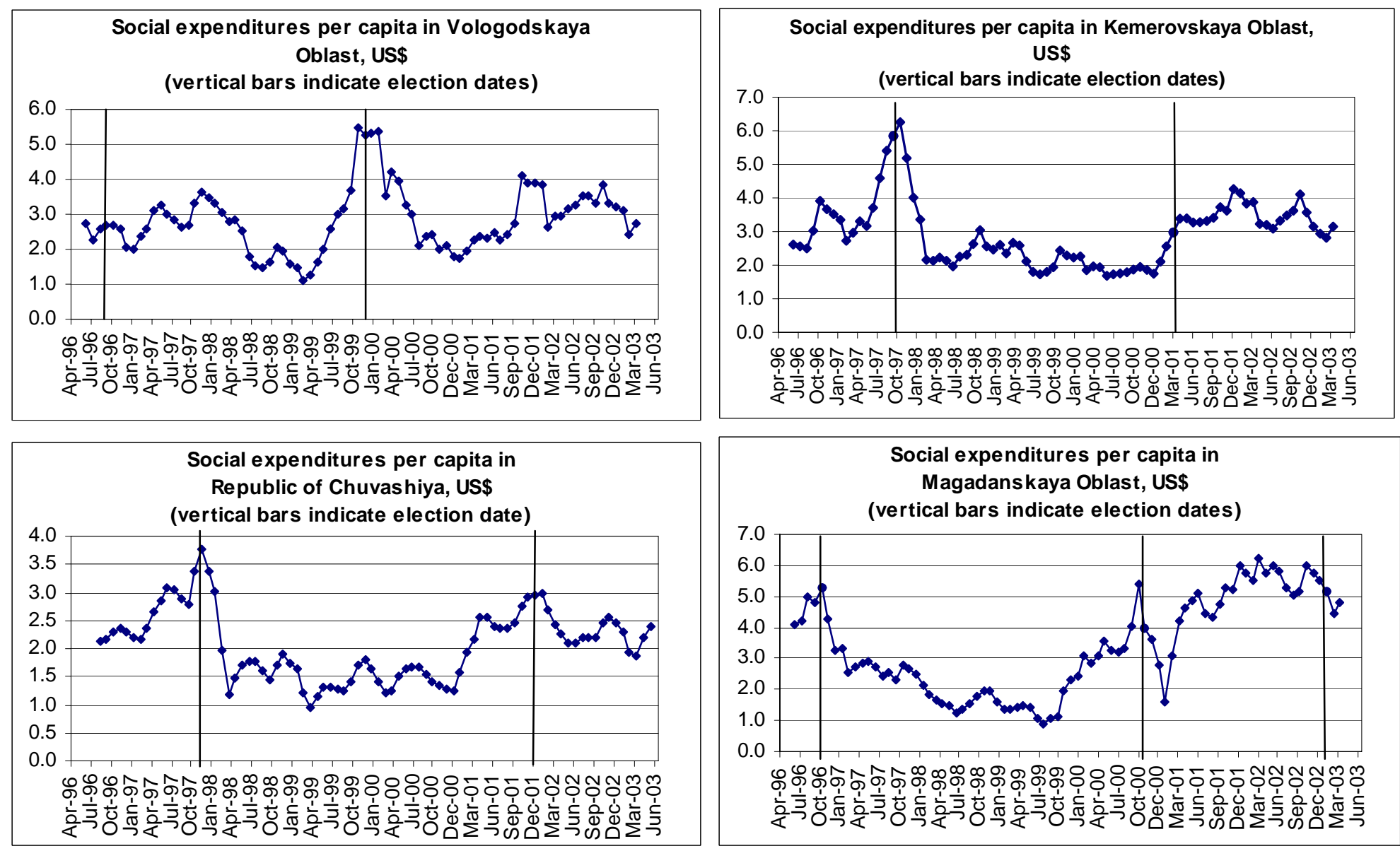
Figure 2. Estimated political budget cycle

Bud. Expenditures

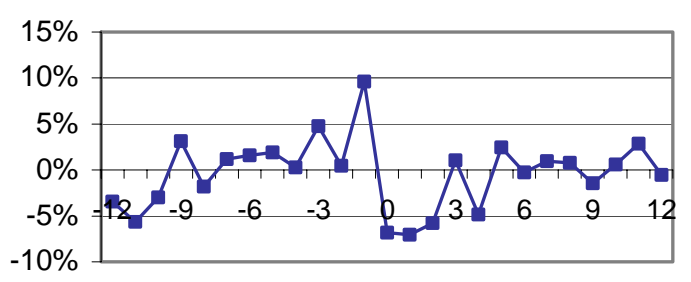

Social Expenditures

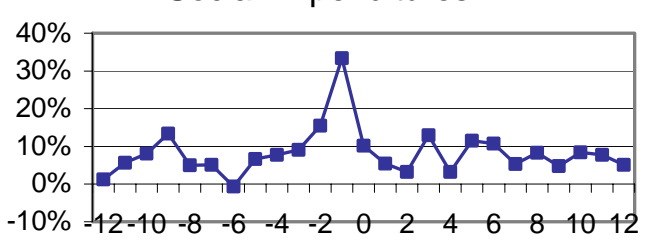

Expenditures on Health

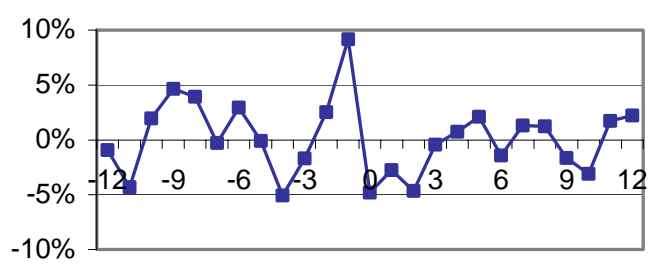

Expenditures on Culture

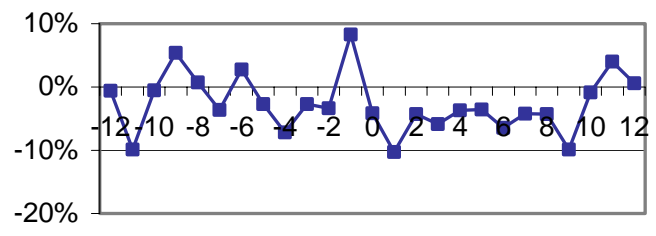

Expenditures on Media

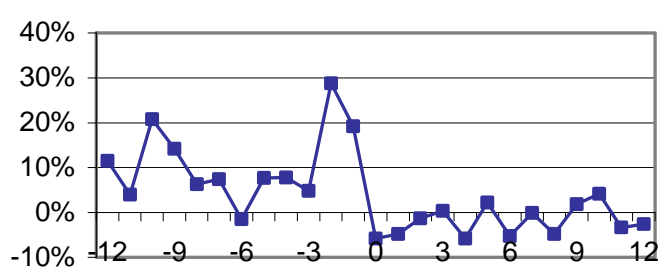

Regional Wage Arrears

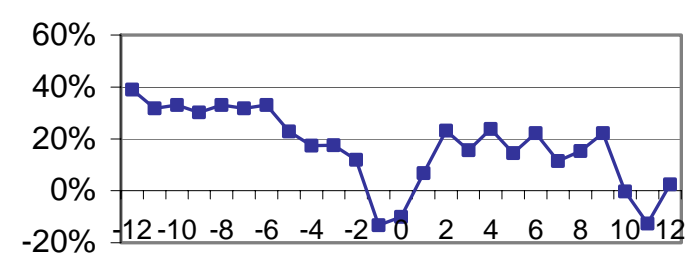

Share of Soc. Exp.

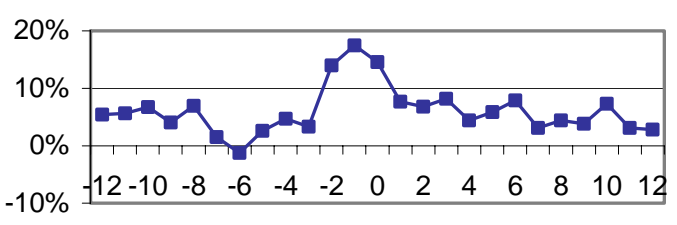

Expenditures on Education

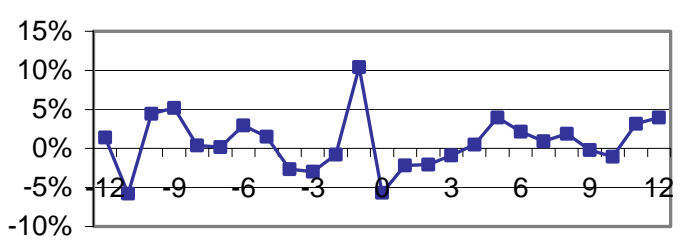

Subsidies to Industry

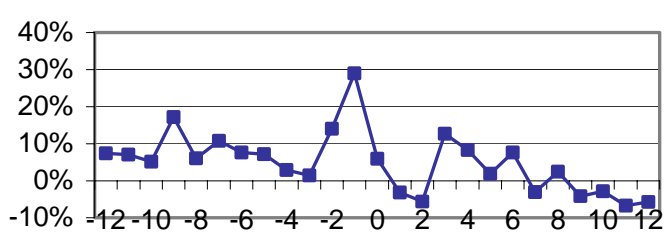

Share of Media Exp.

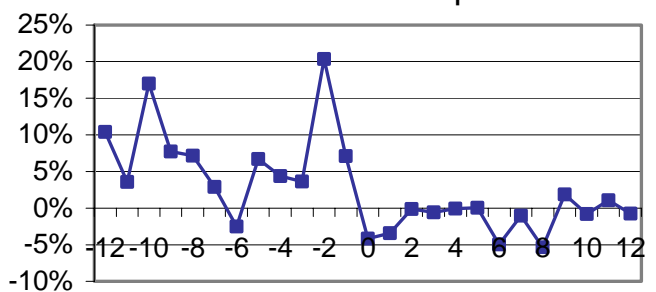


Panel A. Descriptive statistics of policy instruments and outcomes

\begin{tabular}{|c|c|c|c|c|c|c|}
\hline 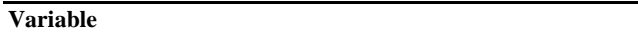 & No. of obs. & Mean & Median & S.E. & Min & Max \\
\hline Total budget expenditures & 7370 & 45.073 & 26.918 & 0.717 & 5.787 & 606.158 \\
\hline Social expenditures & 7522 & 2.905 & 2.102 & 0.035 & 0.183 & 29.365 \\
\hline Share of social expenditures & 7244 & 7.827 & 7.301 & 0.044 & 1.168 & 29.834 \\
\hline Education expenditures & 7528 & 9.284 & 6.115 & 0.118 & 1.287 & 89.396 \\
\hline Expenditures on culture & 7512 & 1.065 & 0.682 & 0.015 & 0.124 & 11.314 \\
\hline Healthcare expenditures & 7524 & 5.949 & 4.122 & 0.070 & 0.828 & 50.709 \\
\hline Media expenditures & 7332 & 0.180 & 0.081 & 0.004 & 0.002 & 3.511 \\
\hline Share of media expenditures & 7210 & 0.372 & 0.301 & 0.003 & 0.024 & 1.762 \\
\hline Expenditures on industry & 7181 & 2.234 & 0.490 & 0.084 & 0.000 & 90.903 \\
\hline Expenditures on agriculture & 7067 & 1.616 & 0.845 & 0.029 & 0.000 & 23.305 \\
\hline Total budget revenues & 7355 & 45.347 & 27.303 & 0.707 & 5.848 & 519.078 \\
\hline Tax revenues & 7542 & 25.755 & 16.716 & 0.392 & 1.540 & 320.622 \\
\hline Ratio of expenditures to revenues & 7094 & 100.102 & 98.469 & 0.283 & 43.474 & 266.375 \\
\hline Growth & 7826 & 0.000278 & 0.000501 & 0.000289 & -0.175 & 0.155 \\
\hline Inflation & 11246 & 0.195 & 0.124 & 0.002 & -0.180 & 1.677 \\
\hline Regional wage arrears & 3870 & 0.006378 & 0.001187 & 0.000354 & 0.000 & 0.246 \\
\hline Wage level & 8410 & 164.614 & 131.095 & 1.135 & 48.215 & 671.721 \\
\hline Money income & 8463 & 125.242 & 102.647 & 0.830 & 31.997 & 566.026 \\
\hline \multicolumn{7}{|l|}{ Panel B. Descriptive statistics of elections } \\
\hline $\begin{array}{l}\text { Variable } \\
\end{array}$ & No. of obs. & Mean & Median & S.E. & Min & Max \\
\hline Dummy for participation of incumbents in elections & 214 & 0.90 & 1 & 0.02 & 0 & 1 \\
\hline Dummy for incumbents' win in elections & 192 & 0.65 & 1 & 0.03 & 0 & 1 \\
\hline Dummy for incumbent coming the third or worse in elections & 192 & 0.06 & 0 & 0.02 & 0 & 1 \\
\hline$\%$ of votes pro incumbent & 192 & 53.98 & 56.23 & 1.65 & 4.76 & 99.9 \\
\hline$\%$ of votes pro main competitor of incumbent & 181 & 32.30 & 28.50 & 1.55 & 0.71 & 82 \\
\hline$\%$ of votes pro winner & 214 & 62.28 & 59.28 & 1.03 & 23.5 & 99.9 \\
\hline$\%$ of votes pro the first runner up & 202 & 24.09 & 24.23 & 0.91 & 0.71 & 48 \\
\hline Number of candidates & 214 & 5.69 & 5 & 0.20 & 1 & 16 \\
\hline Variable & Regions & Mean & Median & S.E. & Min & Max \\
\hline Log of education in 1995 & 76 & 2.78 & 2.75 & 0.03 & 2.19 & 3.68 \\
\hline Log of share of urban population & 86 & 4.17 & 4.23 & 0.03 & 2.91 & 4.61 \\
\hline Index of freedom of media production & 81 & 36.25 & 37 & 1.59 & 0 & 75 \\
\hline Index of democracy & 77 & 2.96 & 3 & 0.10 & 1 & 5 \\
\hline Index of government transparency & 77 & 2.99 & 3 & 0.11 & 1 & 5 \\
\hline
\end{tabular}

